Review

\title{
Improving Resilience of Northern Field Crop Systems Using Inter-Seeded Red Clover: A Review
}

\author{
Amélie C. M. Gaudin *, Sabrina Westra, Cora E. S. Loucks, Ken Janovicek, Ralph C. Martin \\ and William Deen \\ Department of Plant Agriculture, University of Guelph, 50 Stone Road East, Guelph, ON, N1G 2W1, \\ Canada; E-Mails: swestra@uoguelph.ca (S.W.); cloucks@uoguelph.ca (C.E.S.L.); \\ kjanovic@uoguelph.ca (K.J.); rcmartin@uoguelph.ca (R.C.M.); bdeen@uoguelph.ca (W.D.) \\ * Author to whom correspondence should be addressed; E-Mail: agaudind@uoguelph.ca; \\ Tel.: +1-519-824-4120; Fax: +1-519-763-8933.
}

Received: 3 December 2012; in revised form: 28 January 2013 / Accepted: 29 January 2013 /

Published: 8 February 2013

\begin{abstract}
In light of the environmental challenges ahead, resilience of the most abundant field crop production systems must be improved to guarantee yield stability with more efficient use of nitrogen inputs, soil and water resources. Along with genetic and agronomic innovations, diversification of northern agro-ecosystems using inter-seeded legumes provides further opportunities to improve land management practices that sustain crop yields and their resilience to biotic and abiotic stresses. Benefits of legume cover crops have been known for decades and red clover (Trifolium pratense) is one of the most common and beneficial when frost-seeded under winter wheat in advance of maize in a rotation. However, its use has been declining mostly due to the use of synthetic fertilizers and herbicides, concerns over competition with the main crop and the inability to fully capture red clover benefits due to difficulties in the persistence of uniform stands. In this manuscript, we first review the environmental, agronomic, rotational and economical benefits associated with inter-seeded red clover. Red clover adaptation to a wide array of common wheat-based rotations, its potential to mitigate the effects of land degradation in a changing climate and its integration into sustainable food production systems are discussed. We then identify areas of research with significant potential to impact cropping system profitability and sustainability.
\end{abstract}


Keywords: red clover; Trifolium pratense; cropping system; wheat; cover crop; inter-seeding; resilience; input use efficiency

\section{Introduction}

The vulnerability of northern agro-ecosystems to unfavorable climatic conditions has been demonstrated repeatedly, the latest example being in 2012, when both the lack of rainfall and excessive heat reduced by nearly $13 \%$ maize and soybean production across North America and Europe [1]. Northern field crop systems are typically highly fertile and productive temperate environments; characterized by short growing seasons due to sub optimal temperatures for plant growth during late fall, winter and early spring months. Precipitation is usually greater than evapotranspiration in fall and winter and less than evapotranspiration in late spring and summer months. On average, up to $45 \%$ of the maize and wheat and $32 \%$ of the soybean produced worldwide originates from such cropping systems in Europe and North America alone [2], leading to severe impacts of sporadic environmental stresses on world food supplies and prices [3]. There is a consensus in the literature that abnormal production scenarios may become more common as predicted climatic change will lead to warmer and drier conditions in the mid latitude regions with more variable and extreme weather events [4]. Within this context, there is a need to adapt temperate cropping systems to the upcoming changes in climate and resource availability and provide farmers with practical and sustainable solutions to maintain yields under more challenging conditions while using water, nitrogen and soil resources more efficiently.

Cropping sequence diversification using legume cover crops has been advocated for decades as part of the solution to improve field crop system resilience to multiple environmental stresses and improve the sustainable use of nitrogen resources [5-10]. Since the effects of legume cover crops are directly related to the capacity of soil to function, it enables improvement of various aspects of cropping systems, from water and nutrient supply to agro ecological functions. Cover crops have been shown to influence nitrogen cycling [11-13], reduce soil erosion, water run-off and soil losses during intense rainfall events [14-16], increase soil organic matter and soil fertility [17-21], suppress weed growth [22-25], improve soil structure and water holding capacity [26,27], provide suitable habitat for beneficial predator insects and act as non-host crops for nematodes and other pests in the rotation [28]. Legume cover crops also fix their own nitrogen and contribute to the nitrogen requirements of the subsequent crops [29-36].

Those benefits were recognized early in the development of modern agriculture, first in the 5th century by Chinese agriculturists and during the 18th and 19th centuries when red clover (Trifolium pratense) in rotation with Turnip (Brassica rapa L.), maize (Zea mays L.) and other small grain crops was introduced to replace the fallow period in England and North America [37]. However, while the practice of growing cover crops is old, its share in Northern agricultural systems has changed over time and cover crops are currently not utilized to the extent they once were $[38,39]$. Farm practices changed to fit more specialized and intensified agricultural models encouraged by the availability of inexpensive synthetic fertilizers and herbicides and the push for intensification after 
World War II and subsequent agricultural revolutions [28]. Consequently, the use of traditional techniques for sustaining inherent soil fertility, including cover crops and sound crop rotations, decreased and more profitable cropping systems based on external inputs and summer crops expanded.

The most abundant crops in Northern agro-ecosystem rotations are maize, small grains (wheat, barley) and oilseeds (canola, soybean) [40]. In the American Corn Belt, for which surveys on cover crop utilization have been published [38,39], monoculture maize and maize-soybean-cropping systems predominate [41]. Bare soil is frequently exposed to erosion and water runoff over the winter and observations of increased erosion susceptibility as reflected by decreased aggregate stability have been reported in both monoculture maize and maize-soybean rotations [26,42,43]. Depending on residue and nitrogen management, decline in soil organic carbon [44-47], increase in nitrogen leaching [48,49] and weeds [23], pest, and disease pressures [50] have been documented in cropping systems that include maize and soybean in short rotation. Despite the potential of cover crops to address those problems, their widespread use is currently confined to integration into conservation tillage practices in regions prone to soil erosion. Only an estimated $11 \%$ of farmers in the American Corn Belt have used cover crops in their cropping systems between 2001 and 2005 [38,39]. Additional time and cost for establishment, short growing seasons and the lack of economic return in the year that the legume is grown are often the main reasons presented by farmers for not using cover crops [38,39].

Typically, growers prefer a cover crop to occupy an underutilized temporal or spatial niche in the cropping system, thus avoiding the need to significantly alter their crop rotation. The "niche" available in corn and soybean based rotations to establish legume cover crops after a summer annual is small. In Northern cropping systems, the opportunity to include late-season legume cover crops is greatly enhanced with the inclusion of winter wheat or spring wheat (Triticum aestivum L.) in the rotation and no-till seeding systems [51,52]. Legume cover crop can be grown in a relay cropping system where the legume is frost seeded under winter cereals or grown as a companion crop with spring cereals [35,53-56] (Figure 1). Frost-seeded red clover (Trifolium pratense) into an established winter wheat stand have been shown to fix considerable amounts of nitrogen and have a sufficient growing period in temperate regions to establish a viable root system and produce a substantial amount of plant biomass without negatively affecting winter wheat yield [26,54,55,57-59]. Red clover has traditionally been used in advance of maize, in maize-soybean-cereal rotations and has attracted increasing interest since nitrogen fertilizer costs have risen over the past several years [60]. However currently less than $10 \%$ of the wheat acreage is under seeded to this cover crop in Ontario and the trend is to further declines in usage (personal communication, Bill Deen [61]), mostly due to the convenient use of synthetic fertilizers and herbicides, concerns that red clover interferes with straw harvest and the difficulties in establishing uniform stands. 
Figure 1. Representative pictures of inter-seeded red clover grown under winter wheat and stand heterogeneity (2012 field season in Ontario). Double cut red clover in Ontario (a) growing under winter wheat canopy (18 June 2012); (b) after wheat harvest (20 August 2012); scale of stand heterogeneity (c) within a $1 \mathrm{~m}^{2}$ surface area frame and (d) in the field (22 August 2012); (e) red clover prior to first cut (23 September 2012).
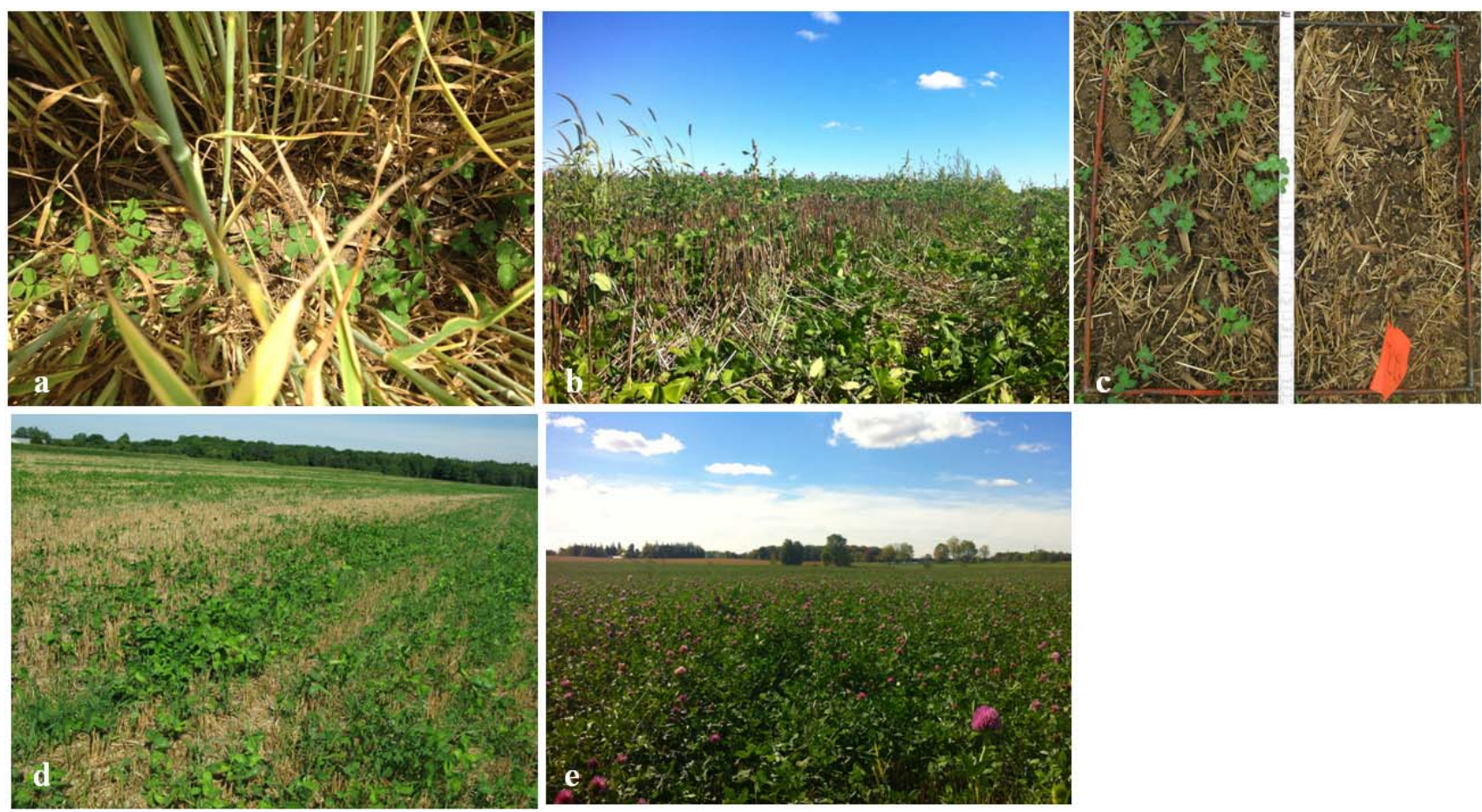

We will make the case that inter-seeded legumes, especially red clover, are part of the solution to improve resilience of maize and wheat-based cropping systems and promote farming practices that do not jeopardize the capacity of the soil to function over the long-term. We will briefly review the current red clover establishment practices and its environmental, agronomic and rotational benefits when inter-seeded. We will explore its potential to mitigate the effects of land degradation in a changing climate, improve input use efficiency and enhance resilience to environmental stresses. We will then discuss the current constraints hampering its use and suggest research that could enable cover crops to become the cornerstone of sustainable and resilient agro-ecosystems.

\section{Current Red Clover Establishment Practices}

Red clover relay cropping with spring or winter cereals offers a practical option for short growing seasons. Red clover can be sown immediately after or simultaneously with spring cereals or frost seeded in early spring under winter cereals. Frost seeding is commonly cited as the most successful strategy for establishing red clover under winter wheat. Seeding while the ground is still frozen minimizes damage to the established grain crop and freeze-thaw cycles and springtime precipitation help improve seed to soil contact [62,63]. Inter-seeding of red clover typically occurs as early as conditions permit in the spring so as to minimize early season competition for irradiance by the cereal crop and improve red clover establishment. Other factors such as red clover variety, planting date, 
seeding rates and wheat management have an effect on red clover establishment and further biomass production.

\subsection{Variety Selection, Seeding Date and Rate}

Two main types of red clover varieties, double cut and single cut, are typically grown as companion crops. Single and double cut types are characterized more by their flowering time than by number of cuts, and both can produce comparable biomass yields over the season [64]. A benefit of using single cut red clover varieties as a cover crop is that it does not flower during the seeding year, which eliminates the risk of unwanted volunteer re-seeding into the following crop. Red clovers can also be split into diploid and tetraploid types. Tetraploids, like the diploids from which they originated, may be of the early flowering double-cut, or late flowering single-cut types. Past studies have found that large variability exists in cultivar performance within different origins and selection histories [25,65] and above-ground dry matter yield of diploid southern cultivars significantly exceeded those of tetraploid northern cultivars in all environments [65]. Single cut and diploids are generally higher yielding than tetraploids and therefore often carry a price premium.

While red clover is considered frost-tolerant and is often sown early to improve establishment, there is some evidence that broadcasting red clover too early may increase the risk of frost injury. Meyer and Badaruddin demonstrated that one-week old red clover seedlings had the highest tolerance to freezing temperatures of $-4{ }^{\circ} \mathrm{C}[66]$ and delaying planting may improve seedling survival by reducing the probability of exposing red clover to freezing temperatures at sensitive stages. Because of limited moisture, planting red clover in the late summer-early fall sequentially after a cereal crop generally results in poor establishment and low biomass yields [59]. Additionally, only $4 \%$ to $27 \%$ of the frost-seeded red clover seeds survive under a winter cereal canopy when averaged across red clover varieties, winter cereal species and seeding rates of both crops [25,65,67-70]. Blaser et al. reported that only $12 \%$ to $15 \%$ of frost-seeded seeds applied at rates of 300 to 1500 seeds $\mathrm{m}^{-2}$ successfully established at wheat harvest while Queen et al. reported stand counts of 23 and 55 plants $\mathrm{m}^{-2}$ out of 450 to 750 frost seeded seeds $\mathrm{m}^{-2}$ [67,71]. Taking into account various experimental results, it has been estimated that red clover stands above 80 plants. $\mathrm{m}^{-2}$ likely provide around $90 \%$ of total maximum dry matter [69]. Most studies found that frost seeding 900 to 1200 seeds $\mathrm{m}^{-2}$ is adequate to exceed this threshold. When clover is sown immediately after or even simultaneously with cereals, lower clover seeding rates are used to reduce competition with the cereal crop [21,72,73].

\subsection{Cereal Management}

Since tillage practices have an effect on soil macroporosity, penetration resistance [74], aggregate stability [26] and soil temperature and water evaporation [75], they may affect red clover germination rates and seedling establishment. Until recently, the effects of winter wheat tillage on final red clover stands and dry matter production remained unclear. Most studies measured the effects of management practices on the main cereal crop [76-78] and further comparisons of tillage systems within studies reporting successful red clover establishment in tilled [79] or no-till systems [54,65,71] were lacking. One recent study, reporting the effects of tillage systems on frost-seeded red clover establishment over six growing seasons in Iowa, showed no significant differences in stand densities, above-ground dry 
matter, and root lengths of red clover harvested from no-till, moderate-till and intensive tillage systems at wheat harvest and 40 days after [80]. In Ontario, a significant decrease in final red clover biomass in absence of tillage ( $\left.644 \mathrm{~kg} \mathrm{ha}^{-1}\right)$ was observed [81] and mixed tillage effects on inter-seeded red clover biomass in spring barley were reported [78]. However, in both studies, red clover plant densities were not shown and results do not strongly support the hypothesis that soil management practices that improve soil structure increase red clover establishment.

In term of nitrogen management, high $\mathrm{N}$ fertilization rates may have a detrimental effect on red clover establishment and growth as nitrogen stimulates weed and cereal competitiveness [71]. However, grain yield and protein content, crucial for high value wheat, increase with increasing amounts of supplemental nitrogen [82]. Doubling the nitrogen fertilization from 25 to $50 \mathrm{~kg} \mathrm{~N} \mathrm{ha}{ }^{-1}$ resulted in a significant reduction in red clover biomass (8.8\%) in one year out of six in Ontario [83]. In those studies, only biomass was considered and it remains unclear whether increasing nitrogen rate caused red clover mortality. Producers can therefore incorporate red clover as a companion crop in the rotation without changing tillage practices and it is recommended to delay nitrogen application, at least until cereal stem elongation, to give the clover enough time to establish [62].

\section{Potential of Inter-seeded Red Clover to Mitigate Land Degradation}

In an agricultural context, land degradation is defined as the gradual destruction or reduction of field productive capacity due to decrease in soil inherent fertility from loss of soil organic matter, nutrients and particle erosion. It in turn leads to accelerated soil erosion by wind and water runoff and changes in soil physiochemical properties with severe implications for crop production. When grown as a companion crop with spring cereals or inter-seeded with winter wheat, red clover allows mitigation of those processes by covering the soil, directly contributing to the soil organic carbon and nitrogen pools with above and below ground biomass decomposition but also through indirect synergistic rotational effects.

\subsection{Direct Biomass Contribution to Soil Organic Matter}

Red clover biomass production and mineralization rate as affected by residue quality and agricultural practices are the main variables acting upon the direct contribution of red clover residues to soil nitrogen and organic matter.

\subsubsection{Biomass Production}

Estimates of red clover above-ground biomass accumulation in a companion crop with spring cereals or inter-seeded with winter wheat have been reported in various studies (Table 1). Most studies report red clover shoot biomass production in the fall prior to onset of winter, ranging from 0.6 to 4.2 $\mathrm{Mg} \mathrm{ha}^{-1}$. Red clover is a short-lived perennial that can over winter and regrows in the spring. Under this scenario, spring above-ground biomass amounts from 1.51 to $5.33 \mathrm{Mg}^{-1}$ have been reported (Table 1). 
Table 1. Variation in final red clover above ground biomass per location and across different management practices reported in the literature.

\begin{tabular}{cccc}
\hline Location & \multicolumn{2}{c}{$\begin{array}{c}\text { Above ground biomass }\left(\mathbf{M g ~ h a}^{-\mathbf{1}}\right) \\
\text { Spring }\end{array}$} & Sources \\
& Fall & $1.71-5.33$ & {$[15,35,71,83-85]$} \\
Ontario & $0.69-4.02$ & $1.51-3.0$ & {$[58]$} \\
Michigan & & & {$[86]$} \\
Wisconsin & $0.86-2.08$ & & {$[65,67,70,80,87]$} \\
Iowa & $0.0-6.52^{(1)}$ & {$[88]$} \\
Saskatchewan & $1.1-1.3$ & {$[54]$} \\
Manitoba & $0.6-1.8$ &
\end{tabular}

${ }^{(1)}$ Dry weight measured 40 days after wheat harvest.

Several studies have also reported below ground dry matter production of red clover with large variation across studies due to the challenges inherent to root measurements and differences in plant age at sampling. Sampling date may have a significant impact on biomass estimates as red clover root production decreases with age along with an increase in the shoot:root ratio [89]. In seven locations in Saskatchewan, shoot:root ratios averaged 4.0 at wheat harvest [88] compared to 8.5 in Iowa at the same time point [80]. Other studies have estimated shoot:root ratios of red clover grown as a sole crop, ranging from 1.49 to 3.83 for first year Trifolium spp. grown in the USA, USSR and Germany [79,89]. Values were considerably lower in Eastern Canada and ranged from 0.83 to 1.01 [90]. However, one must be careful when comparing those estimates, as it is often unclear whether the crown region was considered root or shoot biomass.

Red clover biomass accumulation while the cereal crop is present is minimal $[54,55]$ with the majority of biomass accumulation occurring after cereal harvest and before mechanical or chemical control in the fall or spring (Figure 1a,b,e). For instance, red clover shoot and root dry biomasses were reported to increase by 5.6- and 3.7-fold, respectively, in 40 days following wheat harvest [80]. This pattern can be partially explained by light interception from the wheat canopy. Although differences exist amongst varieties, red clover is considered shade tolerant as it is capable of establishing and surviving under the low radiation environment associated with wheat canopy $[65,71,87]$. Winter wheat canopies intercept from $84 \%$ to $91 \%$ of the total photosynthetically active radiation from late May to early June in Iowa and typically capture more than $77 \%$ of the total radiation for at least 22 days [80].

By acting upon plant competition for light, water and soil resources, variation in the main crop and red clover densities also has a strong effect on biomass accumulation. Greater above-ground red clover biomass production was associated with reduced crop competition and higher red clover density, with an optimum reached at $80-96$ plants $\mathrm{m}^{-2}$ under winter wheat $[73,81]$. When cereal seeding density was increased from 100 to 400 seed $\mathrm{m}^{-2}$, a $30 \%$ decrease in red clover dry biomass after cereal harvest was reported with similar post-wheat harvest red clover densities [68]. However, linear correlations of plant density and dry matter production have been shown to vary with stand count [65] and precipitation levels [71].

Environmental variables such as soil type, precipitation quantity and distribution during the growing season and day length also have an effect on biomass accumulation. Red clover above-ground biomass tends to be lower on coarser soils [55,91] and increasing biomass and red clover stand 
densities have been attributed to higher precipitation levels and a longer growing season $[59,71,77]$. The red clover growing season is mostly determined by the timing of wheat harvest and red clover killing date. Late red clover kill in the spring 1 day prior to no-till maize planting yielded $1.66 \mathrm{Mg} \mathrm{ha}^{-1}$ more biomass on average than when it was chemically controlled 3 weeks earlier [84].

\subsubsection{Decomposition and Mineralization Rates}

After incorporation into the soil, red clover dry matter quickly starts to decompose and organic nitrogen $(\mathrm{N})$ compounds are mineralized to ammonium and nitrate. Fall-harvested red clover has been estimated to contain $10-108 \mathrm{~kg} \mathrm{~N} \mathrm{ha}^{-1}$ and $11-58 \mathrm{~kg} \mathrm{~N} \mathrm{ha}^{-1}$ in the above and below-ground dry matter, respectively. This was similar to nitrogen estimates of spring-harvested biomass that contained $36-111 \mathrm{~kg} \mathrm{~N} \mathrm{ha}^{-1}$ in the above-ground and $21-47 \mathrm{~kg} \mathrm{~N} \mathrm{ha}^{-1}$ in the below-ground dry matter $[36,55,58]$. Across studies, the fertilizer nitrogen equivalent is often poorly correlated with red clover nitrogen content measured in the fall and in the spring. As detailed in Section 4.2.1, possible reasons for this poor relationship include over winter nitrogen losses, variation in mineralization rates and/or poor synchrony between $\mathrm{N}$ mineralized from red clover and subsequent crop $\mathrm{N}$ demand and differences in soil responsiveness.

Mineralization rates largely depend on residue composition (carbon to nitrogen ratios $\mathrm{C} / \mathrm{N}$ ), tillage system, climatic conditions and their interaction [92-94]. The choice of herbicides to terminate red clover growth in the fall or spring can also have a significant impact on biomass $\mathrm{N}$ content, residue decomposition, mineralization rates and microbial activity [95-97]. The effectiveness also varies between active ingredients [98]. Herbicides such as glyphosate, atrazine and glufosinate ammonium have been shown to increase the ammonium content in residues, stimulate microbial activity and mineralization rates and decrease $\mathrm{N}$ immobilization by soil microorganisms due to a raise in the $\mathrm{C} / \mathrm{N}$ ratios [95-97]. Red clover $\mathrm{C} / \mathrm{N}$ ratios typically range from 13.6 to 16.7 resulting in a relatively rapidly net release of nitrogen [36]. In a 2-year study in Wisconsin half of the nitrogen was released within 4 weeks after red clover biomass burial in early spring. Only $\sim 35 \%$ of the original residue nitrogen remained after 10 weeks and very little nitrogen was released afterwards [86]. Those mineralization rates are similar to decomposition patterns of other legumes and may fluctuate with nitrogen content since organisms involved in the mineralization process also require nitrogen [29,92,93,99-102]. Incorporation of red clover residues also enhances wheat straw decomposition in no-till systems, alleviating some of the negative effects of no-tillage on corn emergence and grain yield [75,103]. In general conventional tillage increased soil nitrate levels compared to no-till throughout the growing season $[29,104]$. Red clover residue incorporated in the spring in a conventional tillage system caused nitrate to peak at $44-52 \mathrm{mg} \mathrm{kg}{ }^{-1}$ compared to $22 \mathrm{mg} \mathrm{kg}{ }^{-1}$ when residues were left on the surface in a no-till system [94]. Similarly, rate of mineralization of crimson clover killed in May was greater in conventional tillage than in no-till with lower percentage of initial clover residue remaining after 16 weeks [100]. Residue $\mathrm{C} / \mathrm{N}$ ratio remained unchanged under no-till but declined during the decomposition process from 15.9 to 12.7 under conventional tillage. Rice et al. noted that while no-till soils tended to have less nitrogen mineralization than plowed soils, this effect was only apparent when soil drainage was good [105] and soil water content may impact the oxygen content available for microbiological processes $[81,106]$. 


\subsubsection{Contribution to Soil Organic Matter}

Red clover's contribution of above and below ground dry matter may have a significant impact on soil organic matter levels. However, to date, few studies have actually measured the impact on soil organic matter of red clover inclusion in a rotation [106]. Meyer-Aurich and colleagues did assess red clover impacts on soil organic matter and suggested that inclusion of red clover in rotations does increase total soil organic matter; however results were not statistically significant [107]. Janzen et al. found that cover crops contribute twice as much $\mathrm{N}$ to the organic nitrogen pool in the surface layer as inorganic $\mathrm{N}$ fertilizer [108]. In various studies, uptake of ${ }^{15} \mathrm{~N}$ labeled legume nitrogen was minimal in the second year indicating that legume nitrogen entering the organic nitrogen pool is relatively recalcitrant to further mineralization [108,109]. Red clover cover crops may therefore replenish stable organic nitrogen reserves on the long-term. It is expected that red clover inclusion in rotations will increase total soil organic matter since soil organic matter is correlated with dry matter production of the crop rotation [110].

\subsection{Red Clover Effects on Subsequent Crop Biomass Production}

In addition to the direct contribution to soil organic matter and nitrogen that red clover provides, an indirect contribution through red clover's positive effect on yield of other crops in the rotation is also provided. Increasing complexity of a rotation often results in greater crop yields than when a simple rotation is utilized. The positive effect of rotation complexity on maize has been repeatedly demonstrated [26,107,111-113]. The magnitude of the positive effect of rotation complexity appears to increase when legumes are included $[111,114,115]$ or specifically when red clover is added to the rotation $[26,107,112,116]$.

The yield benefits associated with the inclusion of red clover in a rotation are not exclusively due to nitrogen contributions, although red clover can provide substantial nitrogen contributions to subsequent crops in the rotation $[35,36,55,86]$. Several studies compared maize produced using non-limiting levels of nitrogen with and without a preceding red clover cover crop [35,75,85]. Across these studies, the effect of red clover on maize yields varied from $-7.0 \%$ to $11.6 \%$ with an average yield increase of $2 \%$. This estimate of red clover non-nitrogen benefit may be an underestimate as excess nitrogen from combined red clover and ammonium nitrate application may have caused the 7\% yield reduction observed in one study [85]. Using a compilation of nitrogen responses for maize over a range of soil type and nitrogen responses for maize for the past 40 years in Ontario, it was estimated that rotational effects of red clover in conventional tillage systems could reach up to $7.11 \%$ (Table 2).

Possible explanations for the non-nitrogen associated yield increase under enhanced rotation include fewer pest problems [117], improved plant nutrition [118], increased root activity [119], altered mycorrhizal populations [120] improved precipitation use efficiency [15] and benefits from other soil property enhancements such as improved infiltration, increased mulch cover, and soil moisture conservation $[26,86,99,104,121,122]$. Some of those changes may be connected to the benefits of higher soil organic matter levels from red clover, direct biomass contribution and more indirect synergistic "rotational effects" on soil structural properties. 
Table 2. Analysis of maximum economic rates of nitrogen, yield gains and profits associated with red clover inter-seeded to winter wheat under different tillage systems and maize and nitrogen prices.

\begin{tabular}{|c|c|c|c|c|c|c|c|}
\hline \multirow{2}{*}{$\begin{array}{l}\text { Tillage } \\
\text { system }\end{array}$} & Maize price $^{1}$ & $N$ cost & \multirow{2}{*}{ Cover crop } & \multirow{2}{*}{$\frac{\text { MERN }^{2}}{\mathrm{Kg} \mathrm{N} \mathrm{ha}^{-1}}$} & \multirow{2}{*}{$\frac{\text { MEY }^{3}}{\text { Mg ha }^{-1}}$} & \multirow{2}{*}{$\frac{\text { Gross return }^{4}}{\$ \text { ha }^{-1}}$} & \multirow[t]{2}{*}{ Profit } \\
\hline & $\$ \mathrm{Mg}^{-1}$ & $\$ \mathbf{K g}^{-1}$ & & & & & \\
\hline \multirow{12}{*}{ No-till } & \multirow{3}{*}{150} & \multirow{3}{*}{1} & No red clover & 209 & 9803 & 1278 & \multirow[b]{3}{*}{38} \\
\hline & & & Red clover & 146 & 9899 & 1316 & \\
\hline & & & Difference & $* *$ & $\mathrm{~ns}$ & $\mathrm{~ns}$ & \\
\hline & \multirow{3}{*}{100} & \multirow{3}{*}{1} & No red clover & 189 & 9631 & 791 & \multirow[b]{3}{*}{33} \\
\hline & & & Red clover & 125 & 9719 & 825 & \\
\hline & & & Difference & $* *$ & ns & ns & \\
\hline & \multirow{3}{*}{150} & \multirow{3}{*}{1.5} & No red clover & 189 & 9631 & 1187 & \multirow[b]{3}{*}{70} \\
\hline & & & Red clover & 125 & 9719 & 1257 & \\
\hline & & & Difference & $* *$ & ns & $\mathrm{ns}$ & \\
\hline & \multirow{3}{*}{100} & \multirow{3}{*}{1.5} & No red clover & 158 & 9250 & 713 & \multirow[b]{3}{*}{64} \\
\hline & & & Red clover & 101 & 9421 & 778 & \\
\hline & & & Difference & $* *$ & ns & ns & \\
\hline \multirow{16}{*}{$\begin{array}{c}\text { Conventi } \\
\text { onal } \\
\text { tillage }\end{array}$} & \multirow{4}{*}{150} & \multirow{4}{*}{1} & No red clover & 143 & 9454 & 1293 & \multirow{4}{*}{89} \\
\hline & & & Red clover & 79 & 9886 & 1382 & \\
\hline & & & Difference, & $* *$ & $* *$ & $* *$ & \\
\hline & & & Rotational effect (\%) & & $4.57 \%$ & & \\
\hline & \multirow{4}{*}{100} & \multirow{4}{*}{1} & No red clover & 129 & 9338 & 822 & \multirow{4}{*}{66} \\
\hline & & & Red clover & 74 & 9841 & 888 & \\
\hline & & & Difference & $* *$ & $* *$ & $* *$ & \\
\hline & & & Rotational effect $(\%)$ & & $5.38 \%$ & & \\
\hline & \multirow{4}{*}{150} & \multirow{4}{*}{1.5} & No red clover & 129 & 9338 & 1234 & \multirow{4}{*}{118} \\
\hline & & & Red clover & 74 & 9841 & 1352 & \\
\hline & & & Difference & $* *$ & $* *$ & $* *$ & \\
\hline & & & Rotational effect (\%) & & $5.38 \%$ & & \\
\hline & \multirow{4}{*}{100} & & No red clover & 107 & 9068 & 772 & \\
\hline & & 15 & Red clover & 63 & 9713 & 863 & \\
\hline & & 1.5 & Difference & $* *$ & $* *$ & $* *$ & \\
\hline & & & Rotational effect (\%) & & $7.11 \%$ & & 90 \\
\hline
\end{tabular}

Analysis was conducted using paired comparison of red clover/no red clover for different tillage groups and $\mathrm{N}$ rates on a subset of 28 site-year from the Ontario Nitrogen Database project [79-124]. ${ }^{1}$ Maize price after drying, handling and marketing; ${ }^{2}$ Maximum Economic Rate of Nitrogen (MERN) calculated using quadratic-plateau functions; ${ }^{3}$ Maximum Economic Yield (MEY) at MERN; ${ }^{4}$ Gross return based on nitrogen cost and maize yield at MERN with clover establishment cost estimated at $\$ 40 \mathrm{ha}^{-1}$; ns: non significant; ** significant at $p<0.01$.

\subsection{Improvement of Soil Quality}

Although direct contribution of red clover root system on soil compaction still needs to be investigated, improvements in structure, such as aggregation, associated with increased soil organic matter can be significant and may occur within one season $[125,126]$. Soil organic matter plays a primary role in determining soil aggregation and aggregate stability [127] and exerts its benefits 
largely through its effects on soil aggregation which in turns influences soil susceptibility to erosion from wind and water runoff, crust formation, hard pans, and compaction [125]. Soil erosion occurs when particles detach and are then transported by erosive agents such as water or wind. Better soil aggregation refers to stronger cohesion of primary particle to each other than to the surrounding soil while stability refers to bonding resistance [128]. Better structural properties can mitigate the effects of erosion forces such as impact, shearing, or abrasion that occurs with rain drop impact, water flow, wind, tillage or wheel traffic. Compared to rotations with no red clover, red clover significantly increases wet aggregate stability when under sown to barley or wheat $[15,21,26]$. Crop rotations that include red clover are associated with reduced levels of particle detachment from aggregates and reduced erosion potential [42]. These findings are consistent with other studies that demonstrated soil aggregation increases with increasing proportions of perennial crops, particularly legumes, in a rotation [129-131].

Additionally, when soil particles detach probably by raindrop impact, the permeability of the soils may be reduced when particles seal the surface [132] thereby reducing infiltration rate, increasing runoff and soil erosion potential. Aggregate stability in addition to having a major influence on infiltration of water, will also impact soil water holding capacity, and aeration as well as mass bulk density and penetration resistance [133]. It is also generally agreed that as a colloid, humus is involved in cation exchange capacity, buffer capacity and chelation of metals. All of these processes influence plant water and nutrient availability, yield potential and ultimately, as we will see in the next chapters, the resilience of cropping systems to environmental stresses.

\section{Improving Input Use Efficiencies}

Direct and indirect effects of red clover growth on soil properties may allow better use of water and nitrogen resources within the system and increase cropping system energy efficiency. Although red clover growth can directly affect nitrogen and water cycling, its potential to alter use efficiencies in the cropping system are mostly related to the decomposition of coarse organic matter into soil humic substances. Organic matter affects such a large number of soil properties and processes [134] that a complete discussion is beyond the scope of this paper but we will give insight on how it can influence water and nitrogen gains and losses.

\subsection{Red Clover Helps Improve System Water Use Efficiency}

Water use efficiency (WUE) is the measure of a cropping system's capacity to convert water into crop biomass or grain. Consequently, water use efficiency relies on the soil's ability to capture and store water and the crop's ability to access rainfall and water stored during the growth season. Red clover helps improve WUE within a cropping system by increasing soil water retention, making it more available for the subsequent crop and minimizing water losses through runoff, drainage and evaporation from the soil surface and to weeds [27]. This is possible through direct and indirect effects of red clover above ground and below ground biomass on soil texture, structure, organic matter and microbial activity which all contribute to the soil's ability to capture water, store it and allow plants to develop stronger root systems [134]. Organic matter increases the amount of water a soil can hold and the proportion of water available for plant growth [134-137]. Certain types of organic matter can hold 
up to 10 times their weight in water and it has been estimated that for each $1 \%$ increase in organic matter, the available water capacity of the soil increases by $3.7 \%$ [135]. Since it is a large component of soil volume, increases in organic matter from $0.5 \%$ to $3 \%$ can result in a doubling of the available water capacity. Organic matter also increases the effective soil depth and available water capacity per unit depth [138].

Red clover helps reduce runoff by both holding water on the soil surface long enough for it to enter the soil and reduce the time necessary for the water to permeate. First, red clover provides plant residue and soil cover to protect the soil from sealing and crusting thereby enhancing rainwater infiltration and reducing runoff $[132,133]$. Production of burrow and micropores are also promoted as clover uses excess soil moisture and increases root and worm channels. It in turn improves soil bearing strength and trafficability [139]. Reynolds et al. noted the value of vegetation to keep pores open compared to conventional or no-till management [140]. Additionally, red clover roots improve soil structure and aggregation for better water percolation and drainage [21]. Contrasted with the shallow root system of white clover, red clover's deeper roots can continue growing in mid-summer when many grasses are dormant [141]. Finally, increases in organic matter from biomass incorporation into the organic pool promote downward water flow through macropores and better aggregate stability. Through a combination of those effects, it has been shown that cover crop and plant residues can effectively improve water penetration, decrease water runoff losses by 2 to 6 fold and foster more extensive and deeper root systems for water uptake [14,27].

However, red clover requires water for growth and soil water contents at the time of termination may be lower than if left fallow, depending on the amount and timing of precipitation $[2,10]$. Although when inter-seeded, red clover is usually killed in the fall leaving time for the soil water table to be replenished before the subsequent crop is planted, mixed results may be obtained at a later termination date [58]. Maize response to red clover termination date could be due to depletion of soil moisture, as might occur in years when spring moisture deficits occur. When precipitation was below the long-term average in the coastal plain region of North Carolina, lower soil water content was observed when crimson clover was grown until maize planting with subsequent reduction in maize yields [142]. Results of the study suggested that cover crops should be desiccated 7 to 10 days before planting maize to minimize soil water depletion under dry, early-spring conditions. Yet, reductions in soil moisture at planting do not necessarily cause maize yield depression [58]. In a recent study in Ontario in which red clover was controlled in the spring using a moldboard plow, spring soil moisture was significantly higher in red clover plots versus no red clover [85]. Greater soil moisture with red clover was attributed to either improved water holding capacity, or increased retention of snow and rain. Cover crops mulches or recently terminated cover crops may also reduce soil temperature and thus soil drying, particularly in no-till production systems [143]. Delayed soil warming in the spring may delay tillage, planting and emergence and thus reduce yields [144].

Red clover can have a positive or neutral effect on WUE where infiltration of precipitation is adequate and timely to replenish the soil water and on well-drained soils so that the following crop is not adversely affected by too little or too much water [27]. Ultimately, it has been shown that WUEs under the mixed cropping fields of maize-grasses were much higher than those in the fields where only maize or grasses were grown [145]. 


\subsection{Red Clover Improves Nitrogen Use Efficiency}

Red clover improves cropping system nitrogen use efficiency (NUE) since it allows greater subsequent maximum economic maize yields with less nitrogen (Table 2). By examining the maximum economic rate of nitrogen (MERN) for a range of maize:nitrogen price ratios when maize was preceded or not by red clover under a range of soil types and conventional tillage, a reduction of MERN of 41-64 $\mathrm{kg} \mathrm{N} \mathrm{ha}^{-1}$ was found after red clover cultivation (Table 2). This is due to changes in the balance of nitrogen input over nitrogen losses from the system.

\subsubsection{Effects on Amount and Timing of N Release in the System}

Red clover provides additional nitrogen from $\mathrm{N}_{2}$ fixation directly to the next crop or for storage in the organic pool. Red clover fertilizer nitrogen equivalents in maize have been estimated to an average value of $96.7 \mathrm{~kg} \mathrm{~N}^{-1}$ across studies (Table 1, Section 3.1). However, many studies investigating legume nitrogen mineralization and residue decomposition focused on above-ground biomass, largely under-estimating the amount of nitrogen contributed by roots decomposition [146,147]. Additionally, evaluation of red clover nitrogen transfer to maize using estimates of fertilizer nitrogen equivalents is limited because crop yield and total nitrogen uptake can be affected by red clover induced changes in the soil environment, nitrogen availability and mineralization rates. Various studies have attempted to overcome this concern by using nitrogen isotopes $\left({ }^{15} \mathrm{~N}\right)$ labeled legume residues. Interestingly, these studies indicate that relatively low levels of nitrogen from legumes (15\% to $28 \%)$ are taken up by the first succeeding maize crop $[109,148,149]$ and most of the remaining nitrogen is stored in the soil organic nitrogen fraction [149].

Bergstrom and Kirchmann concluded that only $24 \%$ of red clover derived nitrogen was removed through spring barley grain and stover during two subsequent growing seasons [150]. Those studies also demonstrated that maize [149], winter wheat [108] and spring barley [150] preferably recovered nitrogen fertilizer instead of nitrogen from legume residue decomposition. Values ranged from $29 \%-49 \%$ of $\left(\mathrm{NH}_{4}\right)_{2} \mathrm{SO}_{4}$ nitrogen in maize [149] to $36 \%$ in wheat [108] and $43 \%$ of $\mathrm{NH}_{4} \mathrm{NO}_{3}$ [150] in barley. Lower legume nitrogen recovery levels seem inconsistent with the relatively high fertilizer nitrogen equivalent values indicated above. In a meta-analysis of 217 field-scale studies that followed ${ }^{15} \mathrm{~N}$ in crops, recovery of organic $\mathrm{N}$ source occurred over several years and increased by $71 \%$ in the second growing season. This indicates that short-term studies might underestimate the effect of ecological processes that occur over longer time scales [151]. It has also been suggested that the high nitrogen content of red clover may prime the soil mineralization process, maybe due to a larger and more active microbial population in legume based compared to fertilizer-based systems [149,152,153]. Lower $\mathrm{N}$ uptake percentages might also be explained by dilution of nitrogen from red clover nitrogen into the soil readily available organic pool.

To extract the benefits of inter-seeded red clover in a rotation and maintain high NUE in the system, the release of nitrogen from above and below-ground residues must be well synchronized with the period of nitrogen uptake by the following crop. If red clover mineralization continues beyond, or exceeds crop demand, more $\mathrm{N}$ losses from the system might occur when compared to where the appropriate amount of $\mathrm{N}$ fertilizer was applied without red clover. As explained in an earlier section 
(Section 3.1), variation in the timing of nitrogen release depends on mineralization rates as affected by management practices, environmental condition, residue quality (especially $\mathrm{C} / \mathrm{N}$ ratio) and killing time of red clover. Farmers must therefore carefully consider the effects of their tillage system and its interaction with the timing of red clover biomass burial to maximize economic returns and NUE within the cropping system.

Mineralization of red clover residue incorporated in the spring tends to be well synchronized with maize uptake patterns. It is estimated that red clover releases $50 \%$ of its nitrogen within a month after conventional tillage with little nitrogen remaining after 10 weeks [86]. Some farmers terminate red clover in the fall to avoid delayed soil warming, especially on clay soil. Maize nitrogen uptake increases rapidly during the period of linear vegetative biomass accumulation from V6 to V8 leaf stage and little nitrogen uptake occur during remobilization after the silking stage [154]. Studies have shown when well synchronized, sufficient nitrogen amounts were released such that maize yields using nitrogen fertilizer or red clover residues were similar $[35,86]$.

Kunelius et al. also suggested that red clover may provide small amounts of nitrogen to a cereal, given that alfalfa transfers small amounts of nitrogen (less than $5 \mathrm{~kg} \mathrm{~N} \mathrm{ha}^{-1}$ ) to a competing grass $[73,155]$. Nitrogen amounts transferred are probably minimal, given that red clover accumulates very little biomass when growing below a wheat canopy.

\subsubsection{Effects on N Losses from the System}

In many maize-producing regions, precipitation and evapotranspiration patterns result in a net downward movement of moisture [156]. The potential influence of red clover in mitigating nitrate leaching is probably the result of a combination of effects on water budgets (reduced drainage volume), nitrogen uptake, mineralization process and greater soil water holding capacity. Red clover, like many other cover crops, has been shown to significantly affect soil moisture dynamics. Bergstrom and Kirchmann observed that red clover significantly reduced leachate losses from $575 \mathrm{~mm}$ without cover to $400 \mathrm{~mm}$ with cover [150]. They were able to demonstrate that the reductions were due to increases in soil water holding capacity resulting from incorporation of red clover organic matter. Similarly, conclusions that red clover significantly reduced soil moisture levels in the fall relative to no red clover were observed in Ontario [85] and Manitoba [54]. Red clover can also depress soil nitrate levels in the fall, thereby reducing the quantity of soil nitrate available for leaching [83]. Although legume $\mathrm{C} / \mathrm{N}$ ratios are usually lower [134], studies have demonstrated that fall soil nitrate depression after red clover growth is only slightly lower compared to various other cover crops including oats, ryegrass, and oilseed radish. Nitrate levels can be reduced by $1.1-2.8 \mathrm{mg} \mathrm{NO}_{3}-\mathrm{N} \mathrm{kg}^{-1}$ in the surface $60 \mathrm{~cm}[83]$.

Additionally, red clover may supplement symbiotic $\mathrm{N}_{2}$ fixation with nitrogen uptake from the soil solution to meet all of its nitrogen requirements.

Factors influencing red clover growth potential in the fall may have a significant impact on the ability of red clover to decrease soil nitrogen levels [157]. Application of inorganic nitrogen fertilizer strongly depressed the yield of symbiotic $\mathrm{N}_{2}$ fixation in red clover grown in a mixture with timothy, mainly because of a decrease in the proportion of clover in the sward rather than a direct effect of nitrogen fertilization on symbiosis [158]. However, genetic variability exist among red clover strains 
in their ability to fix $\mathrm{N}$ in response to increased nitrogen fertilization [157]. Results by Bergstrom and Kirchmann suggest that regardless of reductions in soil water and red clover uptake of nitrogen, increased levels of $\mathrm{NO}_{3}$ may still occur [150].

Early or late nitrogen release can result in loss of nitrogen from the system by leaching [86]. Leachates under legume green manure have also been shown to be more important than when non-legume cover crops are used. Meta analysis indicates that red clover might be less efficient at catching soluble nitrogen during growth than cereal species [8]. Potential for loss of nitrogen also occurs during long gaps between red clover kill and subsequent crop growth. During this period, warm temperatures can increase mineralization of organic matter and precipitation can facilitate nitrate leaching [159]. Although red clover is often controlled in the fall when air and soil temperatures are low; carbon and nitrogen transformations may still occur during winter months, with rates depending on carbon degradability and oxygen availability [160,161]. Residue mineralization processes initiated closer to maize planting in the spring did not enhance nitrogen availability compared to autumn killed clover in well-drained Hapludalf soils in Ontario [35] and late termination allows red clover to sequester nitrate in autumn as effectively as other cover crops such as oilseed radish, rye and oat.

Another issue is the effect of red clover on other pathways of nitrogen loss such as nitrous oxide emissions. Crop residues tend to impede soil aeration, and higher $\mathrm{C}$ and $\mathrm{N}$ to the soil thus promoting denitrification and greater $\mathrm{N}_{2} \mathrm{O}$ emissions [162]. One laboratory study reported that addition of red clover residues to the soil increased denitrifying microbial activity with higher $\mathrm{N}_{2} \mathrm{O}$ emissions compared to barley straws [163]. Emissions from nitrogen fixation and cover crop residues may be offset by a reduction in emissions due to decreased nitrogen fertilization as well as an increase in soil carbon sequestration by the cover crop [164]. In a clover-based potato management system in Atlantic Canada, forage and potato crops relying on organic $\mathrm{N}$ sources emitted significantly less $\mathrm{N}_{2} \mathrm{O}$ than those supplemented with inorganic fertilizer while maintaining acceptable yields of both red clover and potatoes [165]. Diversifying maize crop rotations with soybean and wheat inter-seeded with red clover not only results in higher net returns but also in increased mitigation of greenhouse gas emissions up to $1300 \mathrm{~kg} \mathrm{CO}_{2}$ eq ha $^{-1}$ [164].

There is a need to measure the effects of red clover on NUE and WUE at the system level taking into account changes in all pathways of nitrogen and water input and losses. Ultimately, cropping system energy use efficiency has been shown to increase when red clover is used in a rotation. Liebman et al. have estimated that considering a nitrogen fertilizer value of $87-184 \mathrm{~kg} \mathrm{~N}^{-1}$, red clover farmers could reduce energy costs up to $10,488 \mathrm{MJ} \mathrm{ha}^{-1}$ at a fossil energy cost of $57 \mathrm{MJ} \mathrm{kg}^{-1} \mathrm{~N}$ [159]. Estimations under various climate scenarios could also shed light on the possible effects of red clover on cropping system resilience to stresses and environmental impact. For instance, more residual nitrate may remain in the soil at harvest when maize yields are reduced by drought spells. Although the soil may be dryer, higher risks of nitrate leaching may occur with subsequent leaching events.

\section{Effects on Resilience to Environmental Stresses}

Resilience is defined as the propensity of a system to retain its productivity following a perturbation [166]. Thus, a resilient cropping system will provide more stable yields if challenged by biotic and abiotic stresses. Crop diversification including red clover may provide the link between 
stress and resilience because it acts upon the essential resources for crop production and helps build resilient soils. Once again, direct and indirect effects of red clover on soil quality are at the heart of all efforts to mitigate the effects of land degradation and abiotic stresses such as water shortage and high temperature, on agro-ecosystems productivity (Figure 2). Additionally, soil cover and residues provided by red clover may lessen the impact of biotic factors such as pest, disease and weed pressures, on crop production (Figure 2).

Figure 2. Impact of inter-seeded red clover on agro-ecological processes and cropping system resilience to environmental stresses.

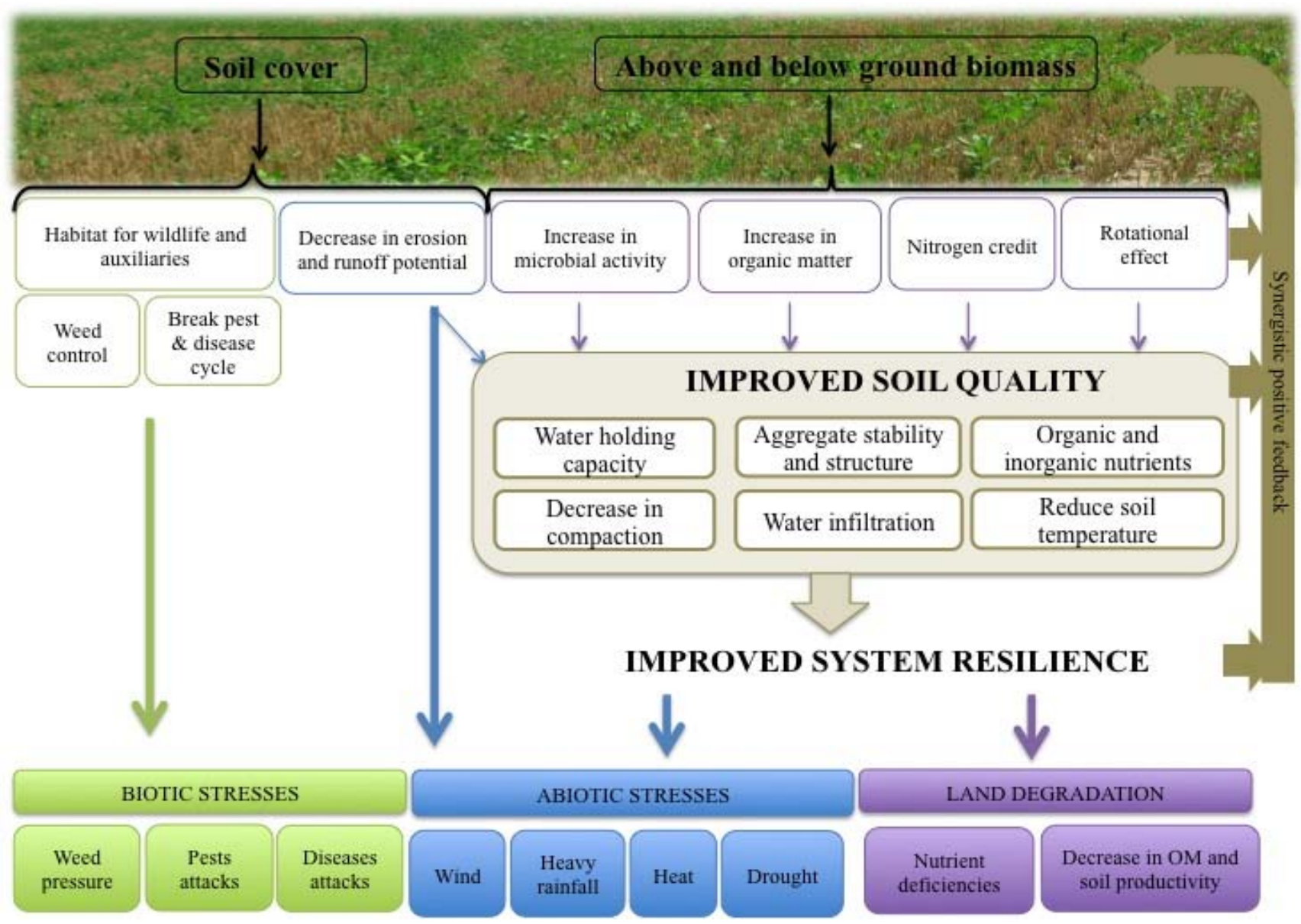

\subsection{Biotic Stresses}

Along with management practices, the pressure of biotic stresses on temperate agro-ecosystems is mostly determined by climatic, soil and biological factors. By intercepting incoming radiation and taking up soil water, red clover biomass and residues affect soil temperature, light quality and quantity and biological activity at various trophic levels in the leaf canopy and underlying soil [167]. This in turn may change the dynamics and pressures of weeds, pests and pathogens during clover growth and the following crop in the rotation. Although clover species are generally considered poor competitors because of their small seed size, lack of seedling vigor, and slow establishment [168], inter-seeded clover has been shown to restrict the negative consequences of late weed development in an efficient way $[22,25,53,57,169-171]$ and significantly reduce perennial weeds, ragweed and mustard 
biomass $[22,25,171]$. However, increased weed densities in the subsequent maize crop can be expected if clover does not establish well [23] and the degree of weed suppression is affected by location, clover growth characteristics, soil fertility and management practices such as mowing and clover density $[25,66,79,141,172]$. Red clover plants may suppress weeds through competition for resources at all phases of the weed cycle [173] compared to residues which act upon weed emergence rather than weed biomass [167] (Figure 1d).

Along with weed suppression, introduction of cereals inter-seeded with red clover improves the system's resilience to pathogens by breaking pests and diseases cycles [174] (Figure 2). Between-season management of weeds may also reduce the risk of pests and disease carried over from the previous season. Winter cereal grains and red clover are excellent crops for suppression of several persistent, soil-borne pests of maize and soybean such as maize rootworm and soybean cyst nematodes [175,176]. Red clover also harbors many beneficial insects [177,178], which may help create biotic barriers for pest outbreaks in the system by providing habitat for a wide array of potential natural enemies.

\subsection{Abiotic Stresses}

While red clover cultivation has a direct impact on biotic stresses, its potential to mitigate abiotic stresses is related to the improvement of soil capacity to function (Figure 2). Sustaining high levels of soil organic matter and biological activity using red clover in the rotation provides the physiochemical foundations for resilient soils (Figure 2). To minimize the impact of drought and high temperature, soils need to capture and store rainwater for future plant use and allow plant roots to penetrate and proliferate $[65,148]$. As mentioned previously, soils with high levels of organic matter have higher water-holding capacity, water infiltration rates and permeability, also necessary for erosion control [148-150,155]. Increasing soil water storage is an important management strategy to minimize the risks of significant crop yield fluctuations associated with highly variable rainfall amount or distribution pattern in northern regions.

Higher soil moisture in turn maintains cooler soil temperatures for a longer period after drought onset [137], decreasing plant water losses. For instance, soil moisture levels remained consistently higher in potato and maize when inter-seeded with living mulches, including clover, than under conventional management $[179,180]$. More aggregated soil structure also fosters more extensive and deeper root systems [127,181], which may make additional moisture available to the crop. The net effect of red clover on soil water conditions ultimately depends on the timing and amount of precipitation, water infiltration and evaporation, and red clover transpiration. Precipitation and infiltration in humid and sub-humid northern regions are generally adequate to replenish the soil water used by red clover in soils with moderate to high water-holding capacities. The effects of red clover on weed control before and during the cropping season are also important to reduce competition for moisture and the use of water from the deep subsoil for weeds which can be extremely valuable to crops during a dry finish to the growing season.

Additionally, organically rich soils usually contain more abundant symbiotic mycorrhizal fungi (e.g., AM fungi), which are a key component of the microbial populations influencing plant growth and improve plant-water interactions. Wheat intercropped with red clover provides a longer period 
without tillage and abundant living plant roots in the soil to host mycorrhizae over a greater duration of time within the crop rotation. Mycorrhizal populations, hyphal densities and inoculum potential have been shown to increase in response to lower disturbance due to tillage and alleviation of some negative impact of tillage on soil properties in a variety of climates and cropping systems [182-187]. This in turn may enhance the services they provide. AM fungi have been reported to increase nutrient uptake in water-stress environments and to enable plants to use water more efficiently $[188,189]$. Finally, soil organic fraction also buffers against land degradation and changes in $\mathrm{pH}$ as it provides a nutrient pool available for mineralization, carbon exchange capacity and chelating agents [134,136]. As soil organic matter decreases, it becomes increasingly difficult for a cropping system to tolerate environmental stresses and fertility, water availability, compaction and erosion problems become more common [134,137,190]. Conversely, some synergistic positive feedbacks effect can be expected as improved soil quality and resilience positively affect yield and above and below ground biomass restitution from subsequent crops to the soil (Figure 2).

Crops are vulnerable to changes in pathogens pressure, temperature and precipitation especially at critical developmental stages such as anthesis. As summarized in Figure 2, through a combination of factors affecting soil structural and biological properties, red clover may alter the timing and severity at which crops sense environmental stresses and help sustain crop yields when biotic and abiotic stresses occur [27,191].

\section{Factors Affecting Red Clover Adoption}

Red clover enhances long-term soil quality and productivity and provides additional opportunities to buffer a wide range of sometime simultaneously occurring environmental stresses on a large scale. However, its adoption by farmers is currently limited [39]. Recent surveys revealed several factors causing farmers reluctance to adopt cover crops and inter-seeded legumes in the US Corn Belt $[39,192]$. The main reasons for this trend include concerns that red clover reduces cereal yields or interferes with harvest of grain or straw. Concerns that benefits do not justify the time and expenses associated with red clover establishment and management and the difficulties in establishing homogeneous stands with synchronized nitrogen restitution to the following crop have also been reported.

\subsection{Misconception about Effects of Inter-Seeded Red Clover on Cereal Yield}

Red clover inter-seeded to a winter cereal does not reduce winter wheat yield nor nitrogen concentration in various environments $[26,54,55,57,58,67,80]$. Although winter wheat whole plant dry matter reductions were reported by Thiessen Martens et al., yields were not affected [54]. Ngalla and Eckert observed 4\% reduction in wheat yield that they attributed to physical damage to the wheat caused by the red clover planting operation rather than red clover competition [193]. Winter wheat yield reductions by red clover are unlikely given that red clover is frost seeded into an established and rapidly growing wheat stand and red clover biomass accumulation during this period is minimal $[54,55,69]$. Documented negative impacts of clover on wheat growth occurred when wheat was seeded over a permanent perennial understory of white clover [194] where yield reductions are likely due to the competition faced by wheat seedlings in a perennial clover population. 
Red clover simultaneously planted with a spring cereal is at less of a competitive disadvantage than when frost seeded to winter wheat. However spring cereals have a high early growth rate and a more substantial root system to effectively compete with clover [72]. Over an eight-year period in a long-term rotation trial conducted under both moldboard and chisel plow tillage systems in Ontario; Raimbault and Vyn demonstrated that red clover had no negative yield impacts on spring barley yields [26]. Hesterman et al. also found no effect of red clover on spring oat yields in Michigan [55]. In comparison, however, red clover inter-seeded to barley consistently reduced barley yields by $10 \%$ on average across five sites in Atlantic Canada [73] but reasons for differences in response over the three studies are not clear.

\subsection{Initial Investments and Net Returns}

From a management perspective, the main hurdle to red clover integration into current cropping system resides is the initial investment of time and cost and farmers' uncertainties about net returns, $[38,39,51,192]$ while technical concerns about a narrow growth season and equipment are more likely a result of lack of knowledge and experience [39].

Economic studies demonstrate positive net benefits of red clover [159,164]. Complex crop rotations including wheat have been shown to have higher net returns compared to continuous maize systems with equivalent net returns for systems including wheat with or without inter-seeded red clover [164]. However, a cost saving from the nitrogen credit was not included in this study. Although the economic benefits of maintaining or increasing soil organic matter are not included, a potentially more realistic estimate of economic gains from red clover can be obtained when taking into account the reduction in nitrogen costs and the increased yield of maize from including wheat and red clover in rotation (Table 2). Nitrogen reductions tended to be lower as the maize to nitrogen price ratio increased with a large effect on the maximum economic yield within a tillage system. The net effect of reductions in nitrogen costs, increased yield revenue, and red clover establishment costs results in \$66.0-\$118.8 ha ${ }^{-1}$ increased profitability for the red clover system (Table 2). Lower nitrogen fertilizer rates for wheat should also be considered since increases in profitability from additional nitrogen can be less than the opportunity cost of productive red clover stands (Table 2).

\subsection{Difficulties in Establishing Homogeneous Red Clover Stands}

Red clover use as a cover crop has declined recently due to its tendency to grow non-uniformly with healthy clover patches of variable size distributed throughout the field [71] (Figure 1c,d). While red clover emerges in a homogenous manner, plant death under a wheat canopy often results in non-uniformity at a small spacial scale (Figure 1c). Since red clover accumulates most of its biomass after the cereal is harvested, uniform survival under the wheat canopy is more of a concern to guarantee uniformity than subsequent biomass accumulation. Several studies have investigated effects of wheat seeding rate, clover seeding rate, tillage and compost amendment on clover stand uniformity with mixed results $[65,77,80]$. Some studies have correlated lower light penetration through the wheat canopy to less successful clover patches [70,71]. In the later studies, soil moisture levels had a more significant impact on red clover stand and biomass across locations and years, especially in the spring. $[73,76,85,88]$. However, there have been no studies so far that examine the direct effect of 
timing, severity and length of water stress on the survival and uniformity of red clover. The impact of non-economic rates of nitrogen to wheat, wheat row spacing, wheat and red clover variety and establishment method also require further examination.

Non-uniformity is a significant problem since environmental benefits and nitrogen value of red clover is questionable if heterogeneous stands are obtained. Farmers that are faced with non-uniform red clover fields tend to not reduce fertilizer application in subsequent crops and are thus investing time, cost and energy into the system without receiving the yield benefits. Over-application of nitrogen in clover-rich patches may also lead to high nitrogen leaching, nitrous oxide emissions and volatilization; however, further research is needed to address these issues and provide farmers with adapted solutions that will maximize environmental benefits and net profits.

\section{Future Prospects for Research}

The main benefits of red clover inter-seeded to cereals and drawbacks hampering the adoption as a sustainable farming practice for a large array of temperate maize and wheat-based cropping systems are summarized in Table 3. Table 3 also emphasizes the research needed to enhance red clover success, profitability and tackle environmental sustainability and resilience issues. One of the main drawbacks acting upon all factors, from profitability to greenhouse gas emissions, is the inability to fully capture red clover benefits due to difficulties in persistence of uniform stands. However, few resources from private and public institutions have been devoted to improve red clover biomass accumulation and stand uniformity under cereals.

Breeding advanced red clover varieties better adapted to growth conditions under a cereal canopy and further investigation of the effect of management practices on stand homogeneity are necessary. Clovers have been traditionally bred for stand persistence as forage in multi-year pasture. A closer look at the literature published from 2008 to 2012 on red clover reflects the current trend in red clover research and breeding targets. Studies on agronomical and physiological properties of red clover in agricultural environments represented $16 \%$ of the total number of publications mentioning "red clover" in their title over the last 5 years (225 publications, Web of knowledge v.5.8), 18\% of which focused on forage production, pasture management and animal diet. $13 \%$ of the total number of studies were related to red clover necrotic virus and more than one third (32\%) of the publications investigated production of biochemical compounds such as isoflavonoids and other health related benefits of red clover. Limited data is available on red clover variety performances when inter-seeded with winter or spring cereals and more information is needed to determine if the interaction between red clover and cereals is important for screening cultivars adapted to inter-seeded systems. Research on additional traits related to red clover completive abilities and growth strategy under wheat stand such as shade, drought and frost tolerance are critical to provide growers with more advanced red clover varieties. Screening of the already characterized natural variation in red clover (10\% of all the studies) could unlock morphological and physiological adaptive traits to enhance establishment. 
Table 3. Main potential benefits and drawbacks of inter-seeded red clover with cereals and current research needs.

\begin{tabular}{|c|c|c|c|}
\hline & Benefits & Drawbacks & Research needed \\
\hline $\begin{array}{c}\text { Management } \\
\text { practices and long } \\
\text { term soil fertility }\end{array}$ & $\begin{array}{l}\text { - Improved soil quality, physiochemical } \\
\text { properties and tilth } \\
\text { - Increase in organic and inorganic soil } \\
\text { nutrients } \\
\text { - Increases flexibility in tillage practices }\end{array}$ & $\begin{array}{l}\text { - Heterogeneous stands and } \\
\text { problems in establishment } \\
\text { - More complex cropping } \\
\text { system management with } \\
\text { potential conflicts in timing } \\
\text { with seeding of fall crops }\end{array}$ & $\begin{array}{l}\text { - Breed advanced red clover varieties for inter-seeding } \\
\text { (drought/cold-tolerant, residue quality) and assess stand success } \\
\text { - Optimize red clover benefits and cereal yields by testing various } \\
\text { red clover/cereal combinations } \\
\text { - Investigate the mechanisms behind heterogeneous stands and test } \\
\text { management practices that could address this issue } \\
\text { - Quantify rotational benefits associated with improved soil quality } \\
\text { and improve red clover integration in multiple cropping systems }\end{array}$ \\
\hline $\begin{array}{c}\text { Profitability and } \\
\text { adoption }\end{array}$ & $\begin{array}{l}\text { - Economical benefits from decreased } \mathrm{N} \\
\text { fertilizer and other inputs and increase } \\
\text { in subsequent crop yields } \\
\text { - Decreased economic risk with rising } \\
\text { energy prices } \\
\text { - Alternative source of income if used } \\
\text { as forage }\end{array}$ & $\begin{array}{l}\text { - Extra time and cost associated } \\
\text { with red clover cultivation } \\
\text { - Low adoption rate by farmers } \\
\text { - Long-term benefits don't } \\
\text { allow for immediate full return } \\
\text { of initial investment } \\
\text { - Heterogeneous stands make } \\
\text { capture of } N \text { benefits difficult }\end{array}$ & $\begin{array}{l}\text { - Systemic approaches to determine all of the benefits of green } \\
\text { manures and incorporate these calculations into farmer returns } \\
\text { - Determining economic, energetic and efficiency-related factors } \\
\text { restraining the use of cover crops by farmers } \\
\text { - Further extension work sharing knowledge on cover crop } \\
\text { implementation for farmers }\end{array}$ \\
\hline $\begin{array}{l}\text { Environmental } \\
\text { sustainability and } \\
\text { resilience }\end{array}$ & $\begin{array}{l}\text { - Decreased pesticide, herbicide and } \\
\text { fertilizer use } \\
\text { - Increasing biodiversity and ecosystem } \\
\text { stability } \\
\text { - Increased system water and nitrogen use } \\
\text { efficiencies } \\
\text { - Buffer for major environmental stresses } \\
\text { - Prevents erosion and soil compaction }\end{array}$ & $\begin{array}{l}\text { - Possible increased in } \mathrm{N}_{2} \mathrm{O} \\
\text { emissions associated with } \\
\text { heterogeneous stands } \\
\text { - Encourages tillage practices to } \\
\text { maximize } \mathrm{N} \text { credit } \\
\text { - Potential extra herbicide } \\
\text { application for fall killing and } \\
\text { extra fuel for mechanically } \\
\text { seeding or fall killing }\end{array}$ & $\begin{array}{l}\text { - Better understanding of the effect of red clover and tillage } \\
\text { practices on greenhouse gas emissions in temperate regions } \\
\text { - Develop methods to better predict the timing and quantity of } \\
\text { nitrogen release into the soil } \\
\text { - Assess the direct and indirect effect of red clover on cropping } \\
\text { system resilience when subjected to abiotic and biotic stresses } \\
\text { - Systemic approach to quantify the effects of red clover on all } \\
\text { pathways of water and nitrogen input, cycling and losses }\end{array}$ \\
\hline
\end{tabular}


Measurements of clover belowground interference factors, and greater understanding of the growth characteristics under a cereal canopy and after harvest will aid the selection of clover species for a particular soil building use and aid decisions about crop-weed/disease management. Research with a range of weeds (e.g., perennials, short species, weeds with low plasticity, and large-seeded weeds) would provide a wider picture of weed interference by clover. Considering the rise in popularity of no-till systems and poor clover survival that have emerged around the same time period [81] more research into the direct or indirect effects of tillage systems on clover establishment should also be conducted.

Development of a systemic approach to quantify the impact of red clover as a companion crop on nitrogen and water use efficiencies, and its energetic, environmental and rotational benefits under different climate scenarios is currently needed. Better communication of those results along with extension and calculation of long-term farmer returns when stresses occur could improve the adoption of this technique.

\section{Conclusions}

Red clover provides through natural means what cannot be brought sustainably into the system through inputs. Therefore, integration of red clover in agricultural systems positively impacts input use efficiencies, economic and environmental net returns and may help increase system resiliency in the face of climate change. A major effort is now underway to develop and implement sustainable agricultural practices, both more environmentally sound and more economically rewarding for farmers. Although there has been a struggle between the environmental necessity to preserve our agro-ecosystems and the economic drive to feed our growing population, economic and environmental goals are merging as energy prices are rising and climate is changing [195,196]. It is generally agreed that more diverse agro-ecosystems have greater ecological stability [106,174]. With shifts in temperature and precipitation patterns, increases in abiotic and biotic stresses due to changes in nutrient cycling, soil moisture, weeds and pathogen occurrences can be expected [7,197]. Crop plants are likely to encounter a greater range of environmental stresses, which may be occurring simultaneously. By breeding additional agricultural system components such as red clover, the overall field crop systems performance, including performance of subsequent high-yielding maize hybrids could be improved at a large scale. As a large amount of resources are currently being invested into crop improvement for tolerance to stresses, complementary agronomical technique such as the one presented here could enhance chances of success of such varieties and sustainably decrease yield gaps when environmental stresses occur.

\section{Conflict of Interest}

The authors declare no conflict of interest.

\section{References}

1. USDA. World Agricultural Production: Monthly Circular Series for World Agricultural Production; USDA: Washington, DC, USA, 2012. 
2. USDA-NASS Commodity Statistics Database. USDA Web site. Available online: http://www. nass.usda.gov/Statistics_by_Subject/index.php?sector=CROPS (accessed on 5 November 2012).

3. FAO Food Price Index Database. FAO Web site. Available online: http://www.fao.org/ worldfoodsituation/wfs-home/foodpricesindex/en/ (accessed on 5 November 2012).

4. Meehl, G.A.; Stocker, T.F.; Collins, W.D.; Friedlingstein, P.; Gaye, A.T.; Gregory, J.M.; Kitoh, A.; Knutti, R.; Murphy, J.M.; Noda, A.; et al. Global Climate Projections. In Climate Change 2007: The Physical Science Basis; Solomon, S.D., Qin, M., Manning, Z., Chen, M., Marquis, K.B., Averyt, M., Miller, H.L., Eds.; Cambridge University Press: Cambridge, UK, 2007.

5. Scholberg, J.M.S.; Dogliotti, S.; Leoni, C.; Cherr, C.M.; Zotarelli, L.; Rossing, W.A.H. Cover Crops for Sustainable Agrosystems in the Americas. In Genetic Engineering, Biofertilisation, Soil Quality and Organic Farming; Lichtfouse, E., Ed.; Springer Netherlands: Dordrecht, The Netherlands, 2010; pp. 23-58.

6. Sainju, U.M.; Whitehead, W.F.; Singh, B.P. Agricultural management practices to sustain crop yields and improve soil and environmental qualities. Sci. World J. 2003, 3, 768-789.

7. Rosenberg, N.J. Adaptation of agriculture to climate change. Clim. Chang. 1992, 21, 385-405.

8. Tonitto, C.; David, M.B.; Drinkwater, L.E. Replacing bare fallows with cover crops in fertilizer-intensive cropping systems: A meta-analysis of crop yield and $\mathrm{n}$ dynamics. Agric. Ecosyst. Environ. 2006, 112, 58-72.

9. Lal, R.; Regnier, E.; Eckert, D.J.; Edwards, W.M.; Hammond, R. Expectations of Cover Crops for Sustainable Agriculture. In Cover Crops for Clean Water; Hargrove, W.L., Ed.; Soil and Water Conservation Society: Ankeny, IA, USA, 1991; pp. 1-11.

10. Lu, Y.-C.; Watkins, K.B.; Teasdale, J.R.; Abdul-Baki, A. Cover crops in sustainable food production. Food Rev. Int. 2000, 16, 121-157.

11. Dinnes, D.L.; Karlen, D.L.; Jaynes, D.B.; Kaspar, T.C. Review and Interpretation: Nitrogen Management Strategies to Reduce Nitrate Leaching in Tile-drained Midwestern Soils; Technical Report for USDA-ARS: Lincoln, NE, USA, 2002.

12. Francis, G.; Bartley, K.; Tabley, F. The effect of winter cover crop management on nitrate leaching losses and crop growth. J. Agric. Sci. 1998, 131, 299-308.

13. Doran, J.W.; Smith, M.S. Role of Cover Crops in Nitrogen Cycling. In Cover Crops for Clean Water; Hargrove, W.L., Ed.; Soil and Water Conservation Society: Ankeny, IA, USA, 1991; pp. 85-90.

14. Langdale, G.W.; Blevins, R.L.; Karlen, D.L.; Mccool, D.K.; Nearing, M.A.; Skidmore, E.L.; Thomas, A.W.; Tyler, D.D.; Williams, J.R. Cover Crop Effects on Soil Erosion by Wind and Water. In Cover Crops for Clean Water; Hargrove, W.L., Ed.; Soil and Water Conservation Society: Ankeny, IA, USA, 1991; pp. 15-22.

15. Dapaah, H.K.; Vyn, T.J. Nitrogen fertilization and cover crop effects on soil structural stability and corn performance. Commun. Soil Sci. Plant Anal. 1998, 29, 2557-2569.

16. Kaspar, T.C.; Radke, J.K.; Laflen, J.M. Small grain cover crops and wheel traffic effects on infiltration, runoff, and erosion. J. Soil Water Conserv. 2001, 56, 160-164.

17. Reicosky, D.C.; Forcella, F. Cover crop and soil quality interactions in agroecosystems. J. Soil Water Conserv. 1998, 53, 224-229. 
18. Willson, T.C.; Paul, E.A.; Harwood, R.R. Biologically active soil organic matter fractions in sustainable cropping systems. Appl. Soil Ecol. 2001, 16, 63-76.

19. Haynes, R.J.; Swift, R.S.; Stephen, R.C. Influence of mixed cropping rotations (pasture-arable) on organic matter content, water stable aggregation and clod porosity in a group of soils. Soil Tillage Res. 1991, 19, 77-87.

20. $\mathrm{Hu}, \mathrm{S}$;; Grunwald, N.J.; van Bruggen, A.H.C.; Gamble, G.R.; Drinkwater, L.E.; Shennan, C.; Demment, M.W. Short-term effects of cover crop incorporation on soil carbon pools and nitrogen availability. Soil Sci. Soc. Am. J. 1997, 61, 901-911.

21. Carter, M.R.; Kunelius, H.T. Effect of undersowing barley with annual ryegrasses or red clover on soil structure in a barley-soybean rotation. Agric. Ecosyst. Environ. 1993, 43, 245-254.

22. Fisk, J.W.; Hesterman, O.B.; Shrestha, A.; Kells, J.J.; Harwood, R.R.; Squire, J.M.; Sheaffer, C.C. Weed suppression by annual legume cover crops in no-tillage corn. Agron. J. 2001, 93, 319-325.

23. Singer, J.; Cox, W.J.; Hahn, R.R.; Shields, E.J. Cropping system effects on weed emergence and densities in corn. Agron. J. 2000, 92, 754-760.

24. Hiltbrunner, J.; Liedgens, M.; Bloch, L.; Stamp, P.; Streit, B. Legume cover crops as living mulches for winter wheat: Components of biomass and the control of weeds. Eur. J. Agron. 2007, 26, 21-29.

25. Mutch, D.R.; Martin, T.E.; Kosola, K.R. Red clover (Trifolium pratense) suppression of common ragweed (Ambrosia) in winter wheat (Triticum aestivum). Weed Technol. 2003, 17, 181-185.

26. Raimbault, B.A.; Vyn, T.J. Crop rotation and tillage effects on corn growth and soil structural stability. Agron. J. 1991, 83, 979-985.

27. Unger, P.W.; Merle, F. Cover crop effects on soil water relationships. J. Soil Water Conserv. 1998, 53, 200-207.

28. Sarrantonio, M.; Gallandt, E. The role of cover crops in north American cropping systems. J. Crop Prod. 2003, 8, 53-74.

29. Varco, J.; Frye, W.; Smith, M.; MacKown, C. Tillage effects on nitrogen recovery by corn from a nitrogen-15 labeled legume cover crop. Soil Sci. Soc. Am. J. 1989, 53, 822-827.

30. McVay, K.; Radcliffe, D.; Hargrove, W. Winter legume effects on soil properties and nitrogen fertilizer requirements. Soil Sci. Soc. Am. J. 1989, 53, 1856-1862.

31. Kuo, S.; Sainju, U. Nitrogen mineralization and availability of mixed leguminous and non-leguminous cover crop residues in soil. Biol. Fertil. Soils 1998, 26, 346-353.

32. Vicia, L.; Roth, V. Winter legumes as a nitrogen source for no-till grain sorghum. Agron. J. 1986, $78,70-74$.

33. Oyer, L.J.; Touchton, J.T. Utilizing legume cropping systems to reduce nitrogen fertilizer requirements for conservation-tilled corn. Agron. J. 1990, 82, 1123-1127.

34. Odhiambo, J.; Bomke, A. Grass and legume cover crop effects on dry matter and nitrogen accumulation. Agron. J. 2001, 93, 299-307.

35. Vyn, T.J.; Faber, J.G.; Janovicek, K.J.; Beauchamp, E.G. Cover crop effects on nitrogen availability to corn following wheat. Agron. J. 2000, 92, 915-924.

36. Bruulsema, T.W.; Christie, B.R. Nitrogen contribution to succeeding corn from alfalfa and red clover. Agron. J. 1987, 79, 96-100. 
37. Pieters, A. Green Manuring, Principles and Practice; John Wiley \& Sons Inc: New York, NY, USA, 1927; p. 356.

38. Singer, J. Corn Belt assessment of cover crop management and preferences. Agron. J. 2008, 100, $1670-1672$.

39. Singer, J.W.; Nusser, S.M.; Alf, C.J. Are cover crops being used in the US Corn Belt? J. Soil Water Conserv. 2007, 62, 353-358.

40. Crop Harvested Area 2010. FAO FAOSTAT Web site. Available online: http://faostat3.fao.org/ home/index.html (accessed on 5 November 2012).

41. Liebig, M.A.; Varvel, G.E.; Doran, J.W.; Wienhold, B.J. Crop sequence and nitrogen fertilization effects on soil properties in the western Corn Belt. Soil Sci. Soc. Am. J. 2002, 66, 596-601.

42. Hussain, S.K.; Mlelke, L.N.; Skopp, J. Detachment of soil as affected by fertility management and crop rotations. Soil Sci. Soc. Am. J. 1988, 52, 1463-1468.

43. Fahad, A.A.; Mielke, L.N.; Flowerday, A.D.; Swartzendruber, D. Soil physical properties as affected by soybean and other cropping sequences. Soil Sci. Soc. Am. J. 1982, 46, 377-381.

44. Miles, R.J.; Brown, J.R. The sanborn field experiment: Implications for long-term soil organic carbon levels. Agron. J. 2011, 103, 268-278.

45. Studdert, G.; Echeverria, H. Crop rotations and nitrogen fertilization to manage soil organic carbon dynamics. Soil Sci. Soc. Am. J. 2000, 64, 1496-1503.

46. Varvel, G.E. Rotation and nitrogen fertilization effects on changes in soil carbon and nitrogen. Agron. J. 1994, 86, 319-325.

47. Havlin, J.; Kissel, D.; Maddux, L.; Claassen, M.; Long, J. Crop rotation and tillage effects on soil organic carbon and nitrogen. Soil Sci. Soc. Am. J. 1990, 54, 448-452.

48. Yamoah, C.F.; Varvel, G.E.; Waltman, W.J.; Francis, C.A. Long-term nitrogen use and nitrogen-removal index in continuous crops and rotations. Field Crop Res. 1998, 57, 15-27.

49. Varvel, G.E.; Peterson, T.A. Residual soil nitrogen as affected by continuous, two-year, and four-year crop rotation systems. Agron. J. 1990, 82, 958-962.

50. Miller, D.R.; Chen, S.Y.; Porter, P.M.; Johnson, G.A.; Wyse, D.L.; Stetina, S.R.; Klossner, L.D.; Nelson, G.A. Rotation crop evaluation for management of the soybean cyst nematode in Minnesota. Agron. J. 2006, 98, 569-578.

51. Snapp, S.S.; Swinton, S.M.; Labarta, R.; Mutch, D.; Black, J.R.; Leep, R.; Nyiraneza, J. Evaluating cover crops for benefits, costs and performance within cropping system niches. Agron. J. 2005, 97, 322-332.

52. Fowler, D.B. Wheat production in the high winter stress climate of the great plains of north America-An experiment in crop adaptation. Crop Sci. 2012, 52, 11-20.

53. Blackshaw, R.E.; Molnar, L.J.; Moyer, J.R. Suitability of legume cover crop-winter wheat intercrops on the semi-arid Canadian prairies. Can. J. Plant Sci. 2010, 90, 479-488.

54. Martens, J.R.T.; Hoeppner, J.W.; Entz, M.H. Legume cover crops with winter cereals in southern Manitoba: Establishment, productivity, and microclimate effects. Agron. J. 2001, 93, 876-883.

55. Hesterman, O.B.; Griffin, T.S.; Willimas, P.T.; Harris, G.H.; Christenson, D.R. Forage Legume-small grain intercrops: Nitrogen production and response of subsequent corn. J. Prod. Agric. 1992, 5, 340-348. 
56. Schipanski, M.E.; Drinkwater, L.E. Nitrogen fixation of red clover interseeded with winter cereals across a management-induced fertility gradient. Nutr. Cycl. Agroecos. 2010, 90, 105-119.

57. Hartl, W. Influence of undersown clovers on weeds and on the yield of winter wheat in organic farming. Agric. Ecosyst. Environ. 1989, 27, 389-396.

58. Tiffin, P.; Hesterman, O.B. Response of corn grain yield to early and late killed red clover green manure and subirrigation. J. Prod. Agric. 1998, 11, 112-121.

59. Stute, J.K.; Posner, J.L. Legume cover crop options for grain rotations in Wisconsin. Agron. J. 1993, 85, 1128-1132.

60. Fertilizer Use and Price Index. USDA-ERS Web site. Available online: http://www.ers.usda. gov/data-products/fertilizer-use-and-price.aspx (accessed on 5 November 2012).

61. Deen, B. University of Guelph, Guelph, Canada. Personal Communication, 2012.

62. Gibson, L.; Singer, J.; Barnhart, S.; Blaser, B. Intercropping Winter Cereal Grains and Red Clover; Technical Report PM 2025 for Iowa State University Extension: Ames, IA, USA, 2006.

63. Clark, A. Red Clover. In Managing Cover Crops Profitably; Sustainable Agriculture Network: Beltsville, MD, USA, 2007; pp. 159-164.

64. Madill, J.; Skepasts, A. Red clover in Ontario; Technical Report No. 81-080 for Ontario Ministry of Agriculture and Food: Toronto, Canada, 1981.

65. Singer, J.; Casler, M.D.; Kohler, K.A. Wheat effect on frost-seeded red clover cultivar establishment and yield. Agron. J. 2006, 98, 265-269.

66. Meyer, D.W.; Badaruddin, M. Frost tolerance of ten seedling legume species at four growth stages. Crop Sci. 2001, 41, 1838-1842.

67. Blaser, B.C.; Gibson, L.R.; Singer, J.W.; Jannink, J.-L. Optimizing seeding rates for winter cereal grains and frost-seeded red clover intercrops. Agron. J. 2006, 98, 1041-1049.

68. Blaser, B.C.; Singer, J.W.; Gibson, L.R. Winter cereal, seeding rate, and intercrop seeding rate effect on red clover yield and quality. Agron. J. 2007, 99, 723-729.

69. Singer, J.; Meek, D.W. Relationship between interseeded red clover biomass and plant number. Crop Sci. 2012, 52, 981-985.

70. Blaser, B.C.; Singer, J.W.; Gibson, L.R. Winter cereal canopy effect on cereal and interseeded legume productivity. Agron. J. 2011, 103, 1180-1185.

71. Queen, A.; Earl, H.; Deen, W. Light and moisture competition effects on biomass of red clover underseeded to winter wheat. Agron. J. 2009, 101, 1511-1521.

72. Garand, M.J.; Simard, R.R.; MacKenzie, A.F.; Hamel, C. Underseeded clover as a nitrogen source for spring wheat on a gleysol. Can. J. Soil Sci. 2001, 81, 93-102.

73. Kunelius, H.T.; Johnston, H.W.; Macleod, J.A. Effect of undersowing barley with Italian ryegrass or red clover on yield, crop composition and root biomass. Agric. Ecosyst. Environ. 1992, 38, 127-137.

74. Katsvairo, T.; Cox, W.J.; van Es, H. Tillage and rotation effects on soil physical characteristics. Agron. J. 2002, 94, 121-125.

75. Drury, C.F.; Tan, C.-S.; Welacky, T.W.; Oloya, T.O.; Hamill, A.S.; Weaver, S.E. Red clover and tillage influence on soil temperature, water content, and corn emergence. Agron. J. 1999, 91, $101-108$. 
76. Brandt, J.E.; Hons, F.M.; Haby, A. Effects of subterranean clover interseeding on grain yield, yield components, and nitrogen content of soft red winter wheat. J. Prod. Agric. 1989, 2, $347-351$.

77. Singer, J.; Cox, W.J. Corn growth and yield under different crop rotation, tillage, and management systems. Crop Sci. 1998, 38, 996-1003.

78. Legere, A.; Stevenson, F.C.; Samson, N. Tillage and weed management effects on forage production in a barley-red clover rotation. Can. J. Plant Sci. 2001, 81, 405-412.

79. Fribourg, H.A.; Johnson, I.J. Dry matter and nitrogen yields of legume tops and roots in the fall of the seeding year. Agron. J. 1955, 47, 73-77.

80. Blaser, B.C.; Singer, J.W.; Gibson, L.R. Winter wheat and red clover intercrop response to tillage and compost amendment. Crop Sci. 2012, 52, 320-326.

81. Deen, B.; Earl, H. Impact of Winter Wheat Management on Underseeded Red Clover. In Proceedings of the American Society of Agronomy International Meeting, Indianapolis, IN, USA, 12-16 November 2006.

82. Nass, H.G.; Papadopolous, Y.; MacLeod, J.A.; Caldwell, C.D.; Walker, D.F. Nitrogen management of spring milling wheat underseeded with red clover. Can. J. Plant Sci. 2002, 82, 653-659.

83. Vyn, T.J.; Janovicek, K.J.; Miller, M.; Beauchamp, E. Soil nitrate accumulation and corn response to preceding small-grain fertilization and cover crops. Agron. J. 1999, 91, 17-24.

84. Janovicek, K.J.; Vyn, T.J.; Voroney, R. No-till corn response to crop rotation and in-row residue placement. Agron. J. 1997, 89, 588-596.

85. Serran, S. Nitrogen Dynamics and Corn Growth in Manure/Cover Crop Systems. Ph.D. Dissertation, University of Guelph, Guelph, Canada, 2005.

86. Stute, J.K.; Posner, J.L. Synchrony between legume nitrogen release and corn demand in the upper Midwest. Agron. J. 1995, 87, 1063-1069.

87. Singer, J.; Sauer, T.J.; Blaser, B.C.; Meek, D.W. Radiation use efficiency in dual winter cereal-forage production systems. Agron. J. 2007, 99, 1175-1179.

88. Bowren, K.; Cooke, D.; Downey, R. Yield of dry matter and nitrogen from tops and roots of sweetclover, alfalfa and red clover at five stages of growth. Can. J. Plant Sci. 1969, 49, 61-68.

89. Bray, J.R. Root production and the estimation of net productivity. Can. J. Bot. 1963, 41, 65-72.

90. Bolinder, M.A.; Angers, D.A.; Bélanger, G.; Michaud, R.; Laverdière, M.R. Root biomass and shoot to root ratios of perennial forage crops in eastern Canada. Can. J. Plant Sci. 2002, 82, 731-737.

91. Mallory, E.B.; Posner, J.L.; Baldock, J.O. Performance, economics, and adoption of cover crops in Wisconsin cash grain rotations: On-farm trials. Am. J. Altern. Agric. 1998, 13, 2-11.

92. Sarrantonio, M.; Scott, T. Tillage effects on availability of nitrogen to corn following a winter green manure crop. Soil Sci. Soc. Am. J. 1988, 52, 1661-1668.

93. Groffman, P.M.; Hendrix, P.F.; Crossley, D.A., Jr. Nitrogen dynamics in conventional and no-tillage agroecosystems with inorganic fertilizer or legume nitrogen inputs. Plant Soil 1987, 97, 315-332.

94. Dou, Z.; Fox, R.; Toth, J. Seasonal soil nitrate dynamics in corn as affected by tillage and nitrogen source. Soil Sci. Soc. Am. J. 1995, 59, 858-864. 
95. Haney, R.L.; Senseman, S.A.; Hons, F.M.; Zuberer, D.A. Effect of glyphosate on soil microbial activity and biomass. Weed Sci. 2000, 48, 89-93.

96. Haney, R.; Senseman, S.; Krutz, L.; Hons, F. Soil carbon and nitrogen mineralization as affected by atrazine and glyphosate. Biol. Fertil. Soils 2002, 35, 35-40.

97. Damin, V.; Trivelin, P. Herbicides Effect on Nitrogen Cycling in Agroecosystems. In Herbicide and Environment; Kortekamp, A., Ed.; InTech: Rijeka, Croatia, 2011.

98. Tradiff, F.; Smith, P. Red Clover Tolerance to Different Herbicide Application Timings; Ontario Ministry of Agriculture and Food: Toronto, Canada, 2005.

99. Ebelhar, S.A.; Frye, W.W.; Blevins, R.L. Nitrogen from legume cover crops for no-tillage corn. Agron. J. 1984, 76, 51-55.

100. Wilson, D.; Hargrove, W. Release of nitrogen from crimson clover residue under two tillage systems. Soil Sci. Soc. Am. J. 1986, 50, 1251-1254.

101. Ranells, N.N.; Wagger, M.G. Nitrogen-15 recovery and release by rye and crimson clover cover crops. Soil Sci. Soc. Am. J. 1997, 61, 943-948.

102. Wagger, M.G. Cover crop management and nitrogen rate in relation to growth and yield of no-till corn. Agron. J. 1989, 81, 533-538.

103. Drury, C.F.; Tan, C.S.; Reynolds, W.D.; Welacky, T.W.; Weaver, S.E.; Hamill, A.S.; Vyn, T.J. Impacts of zone tillage and red clover on corn performance and soil physical quality. Soil Sci. Soc. Am. J. 2003, 67, 867-877.

104. Drinkwater, L.E.; Wagoner, P.; Sarrantonio, M. Legume-based cropping systems have reduced carbon and nitrogen losses. Nature 1998, 396, 262-265.

105. Rice, C.W.; Grove, J.H.; Smith, M.S. Estimating soil net nitrogen mineralization as affected by tillage and soil drainage due to topographic position. Can. J. Soil Sci. 1987, 67, 513-520.

106. Davis, A.S.; Hill, J.D.; Chase, C.A.; Johanns, A.M.; Liebman, M. Increasing cropping system diversity balances productivity, profitability and environmental health. PloS One 2012, 7, 1-8.

107. Meyer-Aurich, A.; Janovicek, K.; Deen, W.; Weersink, A. Impact of tillage and rotation on yield and economic performance in corn-based cropping systems. Agron. J. 2006, 98, 1204-1212.

108. Janzen, H.H.; Bole, J.B.; Biederbeck, V.O.; Slinkard, A.E. Fate of N applied as green manure of ammonium sulphate fertilizer to soil subsequently cropped with spring wheat in three sites in western Canada. Can. J. Soil Sci. 1990, 70, 313-323.

109. Ladd, J.N.; Amato, M.; Jackson, R.B.; Butler, J.H.A. Utilization by wheat crops of nitrogen from legume residues decomposing in the field. Soil Biol. Biochem. 1983, 15, 231-238.

110. Drury, C.; Stone, J.; Findlay, W. Microbial biomass and soil structure associated with corn, grasses, and legumes. Soil Sci. Soc. Am. J. 1991, 55, 805-811.

111. Adams, W.; Morris, H.D.; Dawson., R.N. Effect of cropping systems and nitrogen levels on corn (Zea mays) yields in the southern piedmont region. Agron. J. 1970, 62, 655-659.

112. Henry, D.C.; Mullen, R.W.; Dygert, C.E.; Diedrick, K.A.; Sundermeier, A. Nitrogen contribution from red clover for corn following wheat in western Ohio. Agron. J. 2010, 102, 210-215.

113. Stanger, T.F.; Lauer, J.G. Corn grain yield response to crop rotation and nitrogen over 35 years. Agron. J. 2008, 100, 643-650. 
114. Bolton, E.F.; Dirks, V.A.; Findlay, W.I. Some relationships between soil porosity, leaf nutrient composition and yield for certain corn rotations at two fertility levels on Brookston clay. Can. J. Plant Sci. 1979, 59, 1-9.

115. Miguez, F.E.; Bollero, G.A. Review of corn yield response under winter cover cropping systems using meta-analytic methods. Crop Sci. 2005, 45, 2318-2329.

116. Hively, W.D.; Cox, W.J. Interseeding cover crops into soybean and subsequent corn yields. Agron. J. 2001, 93, 308-313.

117. Benson, G.O. Why the Reduced Yields When Corn Follows Corn and Possible Management Responses. In Proceedings of the Corn and Sorghum Research Conference, Chicago, IL, USA, 11-13 December 1985; pp. 161-174.

118. Copeland, P.; Crookston, P. Crop sequence affects nutrient composition of corn and soybean grown under high fertility. Agron. J. 1992, 84, 503-509.

119. Copeland, J.; Allmaras, R.R.; Crookston, R.K.; Nelson, W.W. Corn-soybean rotation effects on soil water depletion. Agron. J. 1993, 85, 203-210.

120. Johnson, N.C.; Copeland, P.J.; Crookston, R.K.; Pfleger, F.L. Mycorrhizae: Possible explanation for yield decline with continuous corn and soybean. Agron. J. 1992, 84, 387-390.

121. Corak, S.J.; Frye, W.W.; Smith, M.S. Legume mulch and nitrogen fertilizer effects on soil water and corn production. Soil Sci. Soc. Am. J. 1991, 55, 1395-1400.

122. Utomo, M.; Frye, W.W.; Blevins, R.L. Sustaining soil nitrogen for corn using hairy vetch cover crop. Agron. J. 1990, 82, 979-983.

123. Deen, B.; Janovicek, K.; Stewart, G. Influence of Red Clover on Maize Nitrogen Recommendations in Eastern Canada. In Proceedings of IX European Society for Agronomy Congress, Warsaw, Poland, 4-7 September 2006.

124. Janovicek, K.; Stewart, G.A. Updating General Fertilizer Nitrogen Recommendations for Corn in Ontario. In Proceedings of the 34th North Central Extension-Industry Soil Fertility Conference, Des Moines, IA, USA, 17-18 November 2004; pp. 12-19.

125. Angers, D.A.; Mehuys, G.R. Aggregate Stability to Water. In Soil Sampling and Methods of Analysis; Carter, M.R., Ed.; Lewis Publishers: Boca Raton, FL, USA, 1993; pp. 651-658.

126. Stone, J.; Butterly, B. Nine forages and the aggreagtion of a clay loam soil. Can. J. Soil Sci. 1989, 69, 165-169.

127. Six, J.; Elliott, E.T.; Paustian, K. Aggregate and soil organic matter dynamics under conventional and no-tillage systems. Soil Sci. Soc. Am. J. 1999, 63, 350-1358.

128. Kemper, W.D.; Rosenau, R.C. Aggregate Stability and Size Distribution. In Methods of Soil Analysis; Klute, A., Ed.; Soil Science Society of America: Madison, WI, USA, 1986; pp. 425-442.

129. Broersma, K.; Robertson, J.A.; Chanasyk, D.S. The effects of diverse cropping systems on aggregation of a luvisolic soil in the peace river region. Can. J. Soil Sci. 1997, 77, 323-329.

130. Lynch, J.M.; Bragg, E. Microorganisms and Soil Aggregate Stability. In Advances in Soil Science; Stewart, B.A., Ed.; Spriger: New York, NY, USA, 1985; Volume 2, pp. 133-171.

131. Baldock, J.A.; Kay, B.D. Influence of cropping history and chemical treatments on the water-stable aggregation of a silt loam. Can. J. Soil Sci. 1987, 67, 501-511. 
132. Morin, J.; Benyamini, Y.; Michaeli, A. The effect of raindrop impact on the dynamics of soil surface crusting and water movement in the profile. J. Hydrol. 1981, 52, 321-335.

133. Carter, M.R. Soil quality for sustainable land management: Organic matter and aggregation interactions that maintain soil function. Agron. J. 2002, 94, 38-47.

134. Brady, N.C.; Weil, R.R. The Nature and Properties of Soils; Prentice Hall: Upper Saddle River, NJ, USA, 2008.

135. Hudson, B. Soil organic matter and available water capacity. J. Soil Water Conserv. 1994, 49, 189-194.

136. Allison, F.E. Soil Organic Matter and Its Role in Crop Production; Elsevier: Amsterdam, The Netherlands, 1973.

137. Bot, A.; Benites, J. The Importance of Soil Organic Matter; FAO: Rome, Italy, 2005.

138. Patriquin, D. Water, Soil and Organic Matter: A Complex Relationship. The Canadian Organic Grower, Fall 2004. Available online: http://www.cog.ca/documents/Water.pdf (accessed on 9 November 2012).

139. Osborne, S.; Schumacher, T.; Humburg, D. Evaluation of cover crops to increase corn emergence, yield and field trafficability. Agric. J. 2008, 3, 397-400.

140. Reynolds, W.D.; Bowman, B.T.; Brunke, R.R.; Drury, C.F.; Tan, C.S. Comparison of tension infiltrometer, pressure infiltrometer, and soil core estimates of saturated hydraulic conductivity. Soil Sci. Soc. Am. J. 2000, 64, 478-484.

141. Kanneganti, V.R.; Kaffka, S.R. Forage availability from a temperate pasture managed with intensive rotational grazing. Grass Forage Sci. 1995, 50, 55-62.

142. Ewing, R.P.; Wagger, M.G.; Denton, H.P. Tillage and cover crop management effects on soil water and corn yield. Soil Sci. Soc. Am. J. 1991, 55, 1081-1085.

143. Johnson, M.D.; Lowery, B. Effect of three conservation tillage practices on soil temperature and thermal properties. Soil Soc. Sci. Am. J. 1985, 49, 1547-1552.

144. Alessi, J.; Power, J.F. Corn emergence in relation to soil temperature and seeding depth. Agron. J. 1971, 65, 717-719.

145. Lei, T.; Zhan, W.; Xiao, J.; Huang, X.; Mao, J. Water use efficiency of a mixed cropping system of corn with grasses. Int. J. Sustain. Dev. World Ecol. 2009, 12, 37-41.

146. Russell, C.; Fillery, I. Estimates of lupin below-ground biomass nitrogen, dry matter, and nitrogen turnover to wheat. Aust. J. Agric. Res. 1996, 47, 1047-1059.

147. McNeill, A.; Zhu, C.; Fillery, I. Use of in situ ${ }^{15} \mathrm{~N}$-labelling to estimate the total below-ground nitrogen of pasture legumes in intact soil-plant systems. Aust. J. Agric. Res. 1997, 8, 295-304.

148. Sheard, R.W.; Bruulsema, T.W.; Christie, B.R. The Utilization of Nitrogen from ${ }^{15} \mathrm{~N}$-Labelled Legume Residues by Barley. In Proceedings of the 29th National Alfalfa Improvement Conference, Lethbridge, Canada, 15-20 July 1984; p. 34.

149. Harris, G.; Hcsterman, O.B.; Paul, E.A.; Peters, S.E. Fate of legume and fertilizer. Agron. J. 1990, 82, 910-915.

150. Bergström, L.; Kirchmann, H. Leaching and crop uptake of nitrogen from nitrogen-15-labeled green manures and ammonium nitrate. J. Environ. Qual. 2004, 33, 1786-1792.

151. Gardner, J.B.; Drinkwater, L.E. The fate of nitrogen in grain cropping systems: A meta-analysis of ${ }^{15} \mathrm{~N}$ field experiments. Ecol. Appl. 2009, 19, 2167-2184. 
152. Yaacob, O.; Blair, G.J. Effect of legume cropping and organic matter accumulation on the infiltration rate and structure stability of a granite soil under a simulated topical environment. Plant Soil 1981, 60, 11-20.

153. Harris, G.H.; Hesterman, O.B. Quantifying the nitrogen contribution from alfalfa to soil and two succeeding crops using nitrogen-15. Agron. J. 1990, 82, 129-134.

154. Hanway, J.J. Growth stages of corn (Zea mays L.). Agron. J. 1963, 55, 487-492.

155. Burity, H.A.; Faris, M.A.; Ta, T.C.; Coulman, B. Fixation and transfer of nitrogen from legumes to grasses under mixed culture conditions. Plant Soil 1989, 114, 249-255.

156. Davies, D.B.; Sylvester-Bradley, R. The contribution of fertiliser nitrogen to leachable nitrogen in the UK: A review. J. Sci. Food Agric. 1995, 68, 399-406.

157. Boller, B.C.; Nosberger, J. Differences in nitrogen fixation among field-grown red clover strains at different levels of ${ }^{15} \mathrm{~N}$ fertilization. Euphytica 1994, 78, 167-174.

158. Nesheim, L.; Øyen, J. Nitrogen fixation by red clover (Trifolium pratense L.) grown in mixtures with timothy (Phleum pratense L.) at different levels of nitrogen fertilization. Acta Agric. Scand. 1994, 44, 28-34.

159. Liebman, M.; Graef, R.; Nettleton, D.; Cambardella, C.A. Use of legume green manures as nitrogen sources for corn production. Renew. Agric. Food Syst. 2012, 27, 180-191.

160. Dorland, S.; Beauchamp, E.G. Denitrification and ammonification at low soil temperature. Can. J. Soil Sci. 1991, 71, 293-303.

161. Pelletier, F.; Prevost, D.; Laliberte, G.; van Bochove, E. Seasonal response of denitrifiers to temperature in a Quebec cropped soil. Can. J. Soil Sci. 1999, 79, 551-556.

162. Wagnar-Riddle, C.; Furon, A.; Mclaughlin, N.; Lee, I.; Barbeau, J.; Jayasundara, S.; Parkin, G.; Von Bertoldi, P.; Warland, J. Intensive measurement of nitrous oxide emissions from a corn-soybean-wheat rotation under two contrasting management systems over 5 years. Glob. Chang. Biol. 2007, 3, 1722-1736.

163. Miller, M.N.; Zebarth, B.J.; Dandie, C.E.; Burton, D.L.; Goyer, C.; Trevors, J.T. Crop residue influence on denitrification, $\mathrm{N}_{2} \mathrm{O}$ emissions and denitrifier community abundance in soil. Soil Biol. Biochem. 2008, 40, 2553-2562.

164. Meyer Aurich, A.; Weersink, A.; Janovicek, K.; Deen, B. Cost efficient rotation and tillage options to sequester carbon and mitigate GHG emissions from agriculture in eastern Canada. Agric. Ecosyst. Environ. 2006, 117, 119-127.

165. Lynch, D. Environmental impacts of organic agriculture: A Canadian perspective. Can. J. Plant Sci. 2009, 3, 621-628.

166. Holling, C. Resilience and stability of ecological systems. Annu. Rev. Ecol. Syst. 1973, 4, 1-23.

167. Teasdale, J.; Brandsæter, L.; Calegari, A.; Neto, F.S. Cover Crops and Weed Management. In Non-Chemical Weed Management: Principles, Concepts and Techology; Upadhyaya, M.K., Blackshaw, R.E., Eds.; CABI International: Oxfordshire, UK, 2007; pp. 49-64.

168. Nelson, W.A.; Kahn, B.A.; Roberts, B.W. Screening cover crops for use in conservation tillage systems for vegetables following spring plowing. Hortic. Sci. 1991, 26, 860-862.

169. Blackshaw, R.E.; Moyer, J.R.; Doram, R.C.; Boswall, A.L.; Smith, E.G.; Linum, L. Suitability of undersown sweetclover as a fallow replacement in semiarid cropping systems. Agron. J. 2001, 93, 863-868. 
170. Brandsæter, L.O.; Goul Thomsen, M.; Wærnhus, K.; Fykse, H. Effects of repeated clover undersowing in spring cereals and stubble treatments in autumn on Elymus repens, Sonchus arvensis and Cirsium arvense. Crop Prot. 2012, 32, 104-110.

171. Ross, S.M.; King, J.R.; Izaurralde, R.C.; Donovan, J.T.O. Weed suppression by seven clover species. Agron. J. 2001, 93, 820-827.

172. Power, J. Legume and Crop Rotations. In Sustainable Agriculture in Temperate Zones; Francis, C.A., Butler Flora, C., King, L.D., Eds.; John Wisley \& Sons, Inc.: New York, NY, USA, 1990; pp. 178-204.

173. Liebman, M.; Davis, A.S. Integration of soil, crop and weed management in low-external-input farming systems. Weed Res. 2000, 40, 27-47.

174. Lin, B.B. Resilience in agriculture through crop diversification: Adaptive management for environmental change. BioScience 2011, 61, 183-193.

175. Chen, S.; Wyse, D.L.; Johnson, G.A.; Porter, P.M.; Stetina, S.R.; Miller, D.R.; Betts, K.J.; Klossner, L.D.; Haar, M.J. Effect of cover crops alfalfa, red clover, and perennial ryegrass on soybean cyst nematode population and soybean and corn yields in minnesota. Crop Sci. 2006, 46, 1890-1897.

176. Branson, T.F.; Ortman, E.E. The host range of larvae of the western corn rootworm: Further studies. J. Econ. Entomol. 1970, 63, 800-803.

177. Nicholson, A.G.; Wien, H.C. Screening of turfgrass and clovers for use as living mulches in sweet corn and cabbage. J. Am. Soc. Hortic. Sci. 1983, 108, 1071-1076.

178. Skarphol, B.J.; Corey, K.A.; Meisinger, J.J. Response of snap beans to tillage and cover crop combinations. J. Am. Soc. Hortic. Sci. 1987, 112, 936-941.

179. Boyd, N.S.; Gordon, R.; Asiedu, S.K.; Martin, R.C. The effects of living mulches on tuber yields of potato (Solanum tuberosum L.). Biol. Agric. Hortic. 2001, 18, 203-220.

180. Martin, R.C.; Greyson, P.R.; Gordon, R. Competition between corn and a living mulch. Can. J. Plant Sci. 1999, 79, 579-586.

181. Tisdall, J.; Oades, J. Stabilization of soil aggregates by the root systems of ryegrass. Aust. J. Soil Res. 1979, 17, 429-441.

182. Curaqueo, G.; Acevedo, E.; Cornejo, P.; Seguel, A.; Rubio, R.; Borie, F. Tillage effect on soil organic matter, mycorrhizal hyphae and aggregates in a mediterranean agroecosystem. Revista de la ciencia del suelo y nutrición vegetal 2010, 10, 12-21.

183. Brito, I.; Goss, M.J.; de Carvalho, M.; Chatagnier, O.; van Tuinen, D. Impact of tillage system on arbuscular mycorrhiza fungal communities in the soil under Mediterranean conditions. Soil Tillage Res. 2012, 121, 63-67.

184. Brito, I.; Goss, M.J.; de Carvalho, M. Effect of tillage and crop on arbuscular mycorrhiza colonization of winter wheat and triticale under Mediterranean conditions. Soil Use Manag. 2012, 28, 202-208.

185. Jansa, J.; Mozafar, A.; Anken, T.; Ruh, R.; Sanders, I.R.; Frossard, E. Diversity and structure of AMF communities as affected by tillage in a temperate soil. Mycorrhiza 2002, 12, 225-34.

186. Deguchi, S.; Shimazaki, Y.; Uozumi, S.; Tawaraya, K.; Kawamoto, H.; Tanaka, O. White clover living mulch increases the yield of silage corn via arbuscular mycorrhizal fungus colonization. Plant Soil 2007, 291, 291-299. 
187. Lehman, R.M.; Taheri, W.I.; Osborne, S.L.; Buyer, J.S.; Douds, D.D. Fall cover cropping can increase arbuscular mycorrhizae in soils supporting intensive agricultural production. Appl. Soil Ecol. 2012, 61, 300-304.

188. Tobar, R.M.; Azcon, R.; Barea, J.M. The improvement of plant $\mathrm{n}$ acquisition from an ammonium-treated, drought-stressed soil by the fungal symbiont in arbuscular mycorrhizae. Mycorrhiza 1994, 4, 105-108.

189. Karaki, G.N.; Clark, R.B. Growth, mineral acquisition, and water use by mycorrhizal wheat grown under water stress. J. Plant Nutr. 1998, 21, 263-276.

190. Gregorich, E.G.; Carter, M.R.; Angers, D.A.; Monreall, C.M.; Ellerta, B.H. Towards a minimum data set to assess soil organic matter quality in agricultural soils. Can. J. Soil Sci. 1994, 74, 367-385.

191. Griffith, D.R.; Kladivko, E.J.; Mannering, J.V.; West, T.D.; Parsons, S.D. Long-term tillage and rotation effects on corn growth and yield on high and low organic matter, poorly drained soils. Agron. J. 1988, 80, 599-605.

192. Arbuckle, G.; Ferrell, J. Attitudes toward Cover Crops in Iowa: Benefits and Barriers; Technical Report for Iowa State University Extension PMR 1010, Iowa department of Agriculture and Land Stewarship: Ames, IA, USA, 2012.

193. Ngalla, C.F.; Eckert, D.J. Wheat-Red Clover Interseeding As a Nitrogen Source For Corn. In Proceedings of the Annual Conference of the Soil and Water Conservation Society of America, Ankeny, IA, USA, 5 August 1987; pp. 47-48.

194. Jones, L.; Clements, R. Development of a low input system for growing wheat (Triticum vulgare) in a permanent understorey of white clover (Trifolium repens). Ann. Appl. Biol. 1993, 123, 109-119.

195. Agriculture and Agri-Food Canada. Canadian farm fuel and fertilizer: Prices and expenses. Market Outlook Rep. 2010, 2, 1-8.

196. Tilman, D.; Cassman, K.G.; Matson, P.A.; Naylor, R.; Polasky, S. Agricultural sustainability and intensive production practices. Nature 2002, 418, 671-677.

197. Fuhrer, J. Agroecosystem responses to combinations of elevated $\mathrm{CO}_{2}$, ozone, and global climate change. Agric. Ecosyst. Environ. 2003, 97, 1-20.

(C) 2013 by the authors; licensee MDPI, Basel, Switzerland. This article is an open access article distributed under the terms and conditions of the Creative Commons Attribution license (http://creativecommons.org/licenses/by/3.0/). 